\title{
Novel Strategies to Target Mast Cells in Disease
}

\author{
Aida Paivandy ${ }^{a} \quad$ Gunnar Pejler ${ }^{a, b}$

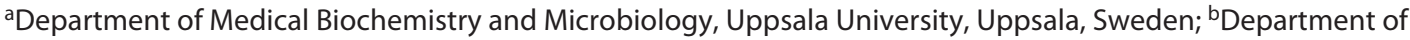 \\ Anatomy, Physiology and Biochemistry, Swedish University of Agricultural Sciences, Uppsala, Sweden
}

\section{Keywords}

Apoptosis · Cytotoxicity · Inflammation · Mast cells

\begin{abstract}
Mast cells (MCs) are versatile effector cells of the immune system, characterized by a large content of secretory granules containing a variety of inflammatory mediators. They are implicated in the host protection toward various external insults, but are mostly well known for their detrimental impact on a variety of pathological conditions, including allergic disorders such as asthma and a range of additional disease settings. Based on this, there is currently a large demand for therapeutic regimens that can dampen the detrimental impact of MCs in these respective pathological conditions. This can be accomplished by several strategies, including targeting of individual mediators released by MCs, blockade of receptors for MC-released compounds, inhibition of MC activation, limiting mast cell growth or by inducing mast cell apoptosis. Here, we review the currently available and emerging regimens to interfere with harmful mast cell activities in asthma and other pathological settings and discuss the advantages and limitations of such strategies.

(c) 2021 The Author(s).

Published by S. Karger AG, Basel
\end{abstract}

karger@karger.com

www.karger.com/jin

Karger $\stackrel{\text { ' }}{=}$

GOPEN ACCESS
(C) 2021 The Author(s)

Published by S. Karger AG, Basel

This is an Open Access article licensed under the Creative Commons Attribution-NonCommercial-4.0 International License (CC BY-NC) (http://www.karger.com/Services/OpenAccessLicense), applicable to the online version of the article only. Usage and distribution for commercial purposes requires written permission.

\section{Introduction}

Mast cells (MCs) are multifaceted effector cells of the immune system [1-5]. They are widely distributed in the body but are particularly abundant in tissues that are portals of entry for external insults. MCs are equipped with a broad range of sensors that enable the recognition of various stimuli, and they respond to such stimuli by releasing a panel of inflammatory compounds. This enables MCs to play a key role in orchestrating inflammation, which can be utilized in the host defence against infectious agents [6-9]. On the other hand, dysregulated MC activation can contribute to the pathogenesis of allergic conditions, including asthma and atopic dermatitis, and also to other pathological settings such as cutaneous mastocytosis, fibrosis, cancer, and psoriasis [2-4, 10-12]. Thus, strategies that target MCs can potentially be adopted for treatment of such diseases. Here, we briefly describe the basic properties of MCs, with a particular emphasis on their role in asthma and then discuss available MC-directed therapies for treatment of asthma and other pathological conditions.
Aida Paivandy

Department of Medical Biochemistry and Microbiology, Uppsala University BMC, Box 582

SE-75123 Uppsala (Sweden) aida.paivandy@imbim.uu.se 
Fig. 1. MC activation and mediator release. MCs become activated when IgE molecules bound to surface FceRI are cross-linked by antigens (e.g., allergen). Such activating signals lead to the release of preformed mediators through degranulation as well as de novo production and release of several other mediators. MC, mast cell.

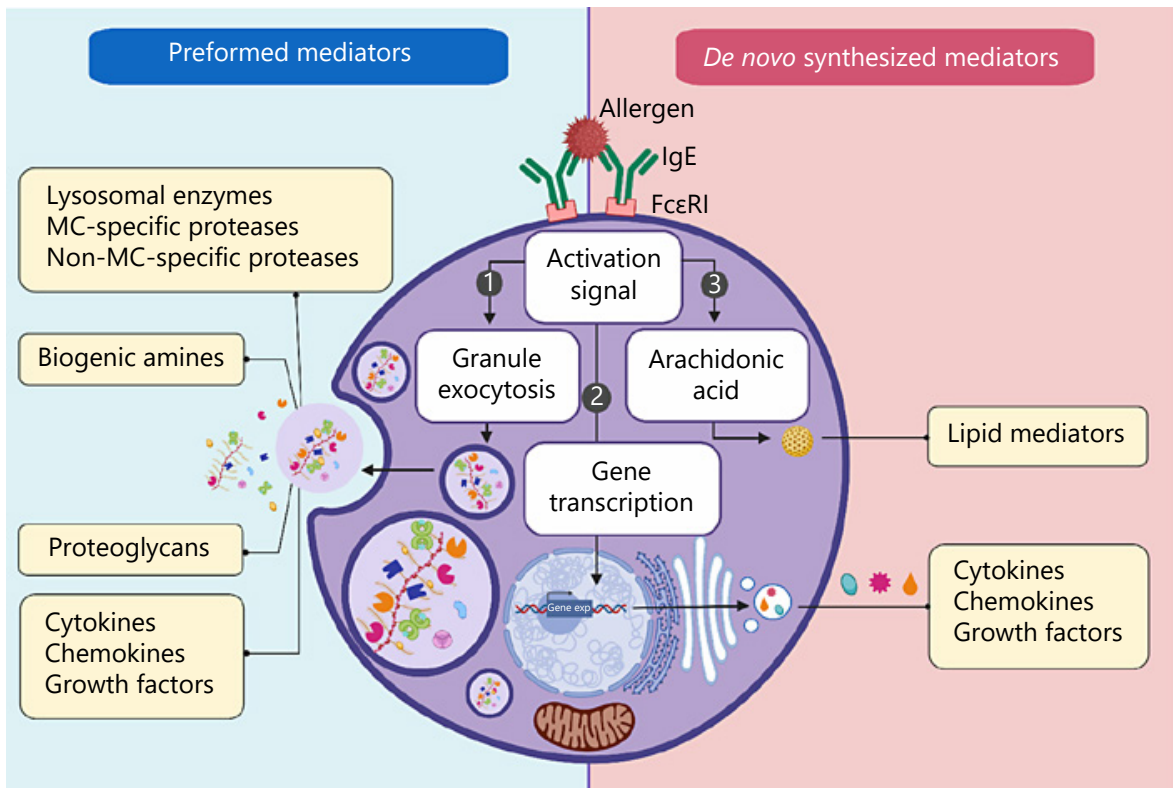

Table 1. Examples of MC-derived mediators

\begin{tabular}{ll}
\hline Mediator class & Mediators \\
\hline $\begin{array}{l}\text { Preformed (immediate release) } \\
\text { Lysosomal enzymes }\end{array}$ & Cathepsins (B, C, D, E, L) and $\beta$-hexosaminidase \\
Non-MC-specific proteases & Cathepsin G, Granzyme B, ${ }^{1}$ and Active caspase-3 \\
MC-specific proteases & Tryptases, ${ }^{1}$ chymases, ${ }^{1}$ and CPA3 ${ }^{1}$ \\
Proteoglycans & Serglycin (heparin and chondroitin sulphate) \\
Biogenic amines & Histamine ${ }^{1}$ and serotonin ${ }^{1}$ \\
Cytokines and chemokines & TNF, IL-4, CCL5, and CXCL8 \\
Growth factors & SCF, VEGF, FGF, NGF, and TGF- $\beta$ \\
\hline
\end{tabular}

De novo synthesized (delayed release)

Lipid mediators

Cytokines

Chemokines

Growth factors
PGD2, PGE2, LTB4, LTC4, and PAF

TNF, IFN $\gamma$, IL-1, $-2,-3,-4,-5,-6,-9,-10,-13$, and -33

CCL1, 2, 3, 4, 5, 7, 11, 17, 20, and 22; CXCL2, 8, and 10

SCF, VEGF, FGF, NGF, TGF- $\beta$, PDGF, and GM-CSF

CPA3, carboxypeptidase A3; FGF, fibroblast growth factor; LTC4, leukotriene C4; GM-CSF, granulocyte macrophage colony-stimulating factor; IFN, interferon; LT, leukotriene; MC, mast cell; NGF, nerve growth factor; PAF, platelet activating factor; PDGF, platelet-derived growth factor; PG, prostaglandin; SCF, stem cell factor; TGF- $\beta$, transforming growth factor- $\beta$; TNF, tumour necrosis factor; VEGF, vascular endothelial growth factor. ${ }^{1}$ Examples of mediators that are dependent on serglycin for their storage. Data retrieved from $[16,19,20]$.

\section{MCs: General Properties and Role in Asthma}

MCs are long-lived tissue-resident cells that originate from hematopoietic pluripotent progenitors in the bone marrow [13-17], but can also be derived from the yolk sac [18]. As MCs mature, they acquire an abundance of secre- tory granules [19]. The secretory granules are densely packed with large quantities of various preformed mediators, including biogenic amines, MC-specific proteases, lysosomal enzymes, certain cytokines, chemokines, growth factors, and serglycin proteoglycans [16, 19]. These preformed mediators are released into the extracel- 
Table 2. Activating and inhibitory receptors expressed by MCs.

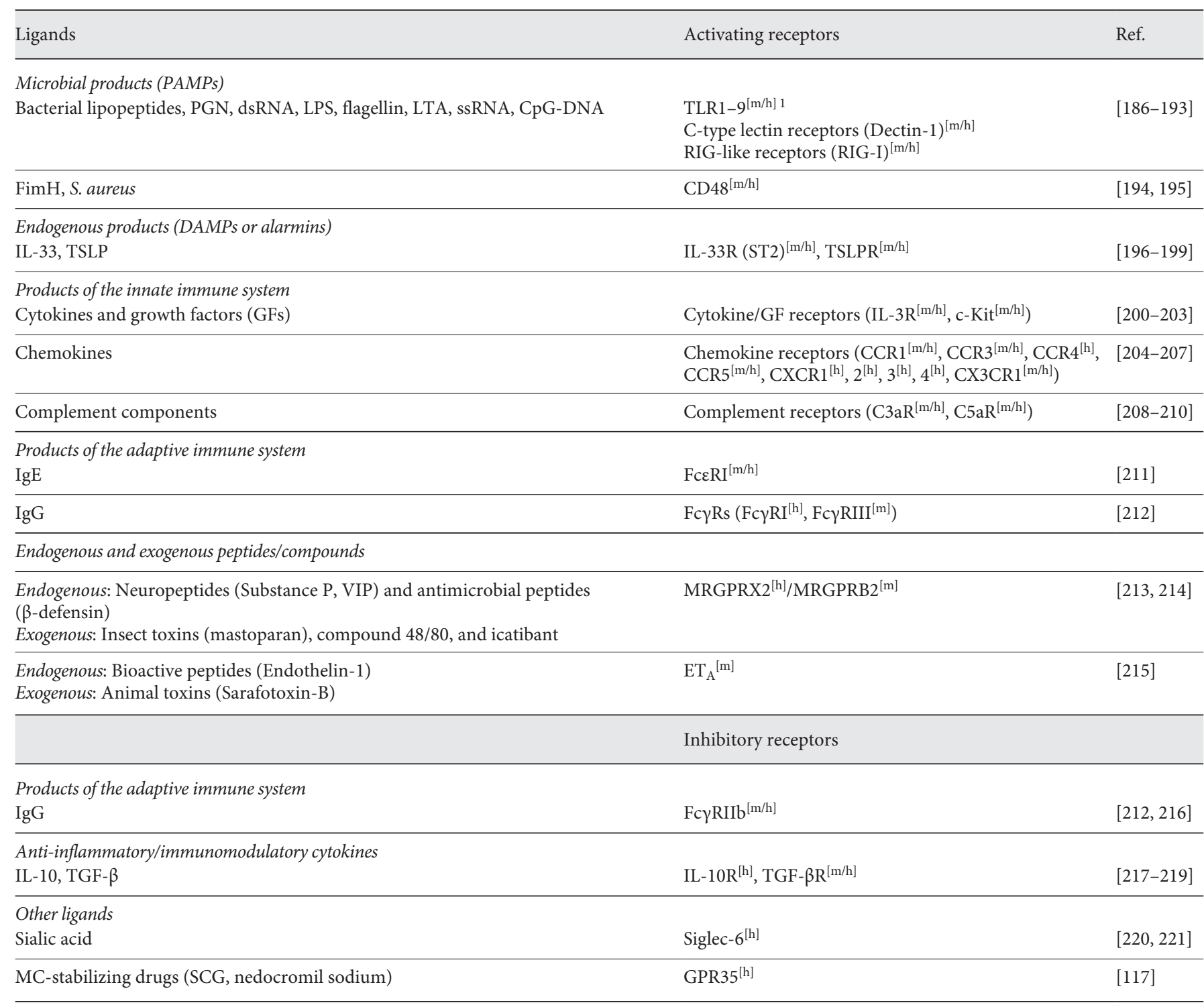

DAMP, damage-associated molecular pattern; dsRNA, double-stranded RNA; GPR35, G-protein-coupled receptor 35; LPS, lipopolysaccharide; LTA, lipoteichoic acid; MC, mast cell; MRGPR, MAS-related G protein-coupled receptor; PAMP, pathogen-associated molecular pattern; PGN, peptidoglycan; SCF, stem cell factor; SCG, sodium cromoglycate; Siglec-8, sialic acid binding Ig-like lectin-8; ssRNA, single-stranded RNA; TGF- $\beta$, transforming growth factor- $\beta$; TNF, tumour necrosis factor; TSLP, thymic stromal lymphopoietin; VIP, vasoactive intestinal polypeptide. Data retrieved from [117, 222-229]. ${ }^{1} \mathrm{~m}$, expressed in mouse MCs; h, expressed in human MCs.

lular environment when MCs are activated to degranulate, a process that can be accomplished by IgE-mediated and a range of other mechanisms [2]. In addition to the release of preformed granule constituents, MC activation leads to de novo synthesis and release of a diverse array of additional bioactive mediators [16, 19, 20] (Fig. 1; Table 1).

Targeting Mast Cells
MCs are present in virtually all vascularized tissues but are particularly abundant at junction points of the body and external environment (e.g., skin, gastrointestinal tract, and airways) $[1,16]$. Mature MCs can express a large panel of sensory receptors, enabling them to respond to a wide variety of stimuli (Table 2) $[2,6,16]$. These features enable MCs to serve as immune sentinel cells acting in the first-line defence following encounter 
with a tissue insult. MCs can also communicate with other immune cells to promote their recruitment to the affected tissues [2, 16]. Altogether, MCs thereby play an important role in initiating inflammation, in modulating both innate and adaptive immune responses, and in tissue repair and homeostatic maintenance [16, 21]. However, if the tissue insult is repeated or persistent, such as in chronic inflammatory conditions, sustained MC activation can have potentially harmful consequences $[16,22$, 23]. MCs can thereby play both beneficial and detrimental roles for the organism. Examples of beneficial roles of MCs include their involvement in protection against certain animal venoms [24-26] and various types of infections $[6-9,27,28]$. However, MCs are undoubtedly best known for their detrimental roles in allergies and related diseases, such as asthma, allergic rhinitis, and atopic dermatitis [10,29]. Moreover, a growing body of evidence is implicating MCs as detrimental players in several other human diseases, including various autoimmune disorders $[30,31]$, cancers $[16,32]$, mastocytosis $[33,34]$, chronic obstructive pulmonary disease $[35,36]$, and atherosclerosis [16, 37].

The central role of MCs in the pathogenesis of allergic diseases, for example, asthma, is supported by several lines of evidence. For example, asthmatic patients have increased numbers of lung MCs, especially in locations such as the airway smooth muscle layer, lung epithelium, and alveolar parenchyma [38-40]. Moreover, a higher number of MCs has been found in the distal airways of individuals with non-fatal and fatal asthma compared to non-asthmatic controls [41]. Of note, the abnormal accumulation of MCs in these lung compartments has been associated with enhanced asthma symptoms [38, 40, 42, 43]. In line with these observations, an increased percentage of degranulated MCs has been found in the mucous glands in cases of fatal asthma compared to non-fatal asthma and controls [44]. The extensive MC degranulation in fatal asthma suggests that MCs are highly activated in severe asthma $[44,45]$. Importantly, a role for MCs in asthma is also supported by a number of studies conducted on mice [46-48]. In mouse models of allergic asthma, elevated numbers of airway MCs are found and MCs have been demonstrated to contribute in a major way to several symptoms associated with experimentally induced allergic airway inflammation, including eosinophilic airway inflammation, enhanced airway hyperresponsiveness (AHR) to methacholine or antigen, goblet cell hyperplasia, and enhanced mucus production [47].

MCs are recognized as effector cells in all phases of asthma, that is, the early, late, and chronic phases [23, 29].
Although MCs are thought to be of particular importance in allergic asthma, they can also have an impact on asthma caused by non-allergic mechanisms such as those seen in non-atopic, occupational, and exercise-induced asthma [23]. In the early phase, MCs release mediators such as histamine, prostaglandin D2 (PGD2), and leukotriene C4 (LTC4), hence contributing to the bronchoconstriction, respiratory mucosal oedema, and mucus secretion $[16,23,49-56]$. The central role of these MC mediators is supported by observations indicating that potent and selective receptor antagonists of histamine [57, 58], LTC4 $[59,60]$, and to a lesser degree PGD2 [61], can markedly attenuate early-phase asthmatic reactions. In late-phase asthmatic reactions, proinflammatory mediators released by MCs, including cytokines and chemokines, contribute to the recruitment of inflammatory cells such as eosinophils, basophils, $\mathrm{CD} 4^{+} \mathrm{T}$ cells, and macrophages to the airways, leading to airway obstruction and AHR [23]. Notably, it has been found that anti-IgE therapy markedly attenuates the late-phase asthmatic reactions [62], indicating that MC (and/or basophil) activation during the early phase initiates events leading to the late-phase reactions [23]. Lastly, when allergen exposure is continuous or repetitive, early- and late-phase reactions develop into a chronic phase that is associated with persistent inflammation, tissue remodelling, and fibrosis [29]. In chronic allergic asthma, ongoing MC activation and degranulation is observed [23]. In line with this, increased levels of MC products, such as histamine and tryptase, have been found in bronchoalveolar lavage (BAL) fluid from asthmatics compared to healthy controls [52, 63-66]. Additionally, MCs within the bronchial mucosa of asthmatics produce various cytokines, including IL-4, IL-5, IL-6, IL13, TNF- $\alpha$, and TSLP [67-72].

\section{Therapeutic Approaches to Target MCs in Disease}

Given the well-recognized harmful role of MCs in allergic and other disorders, there is an urgent need to identify efficient strategies that can limit the detrimental effects of MCs in such settings. Currently, there are several therapeutic approaches available for this purpose. In general, the aims of these approaches are to either (i) inhibit MC-derived mediators or their effects, (ii) inhibit MC activation, or (iii) reduce MC numbers. Below, some of the therapeutic anti-MC options that are currently used in the clinic or are being considered for future use are discussed (Fig. 2). 


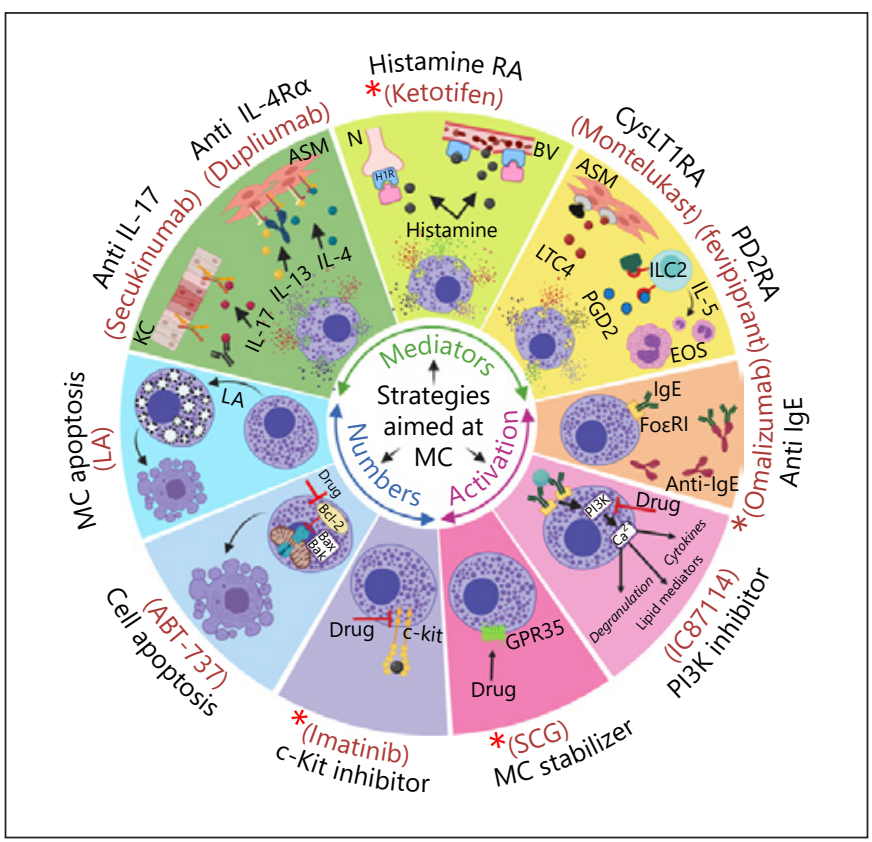

Fig. 2. Overview of therapeutic strategies aiming at the inhibition of mast cell mediators or activation, and reduction of mast cell numbers. ASM, airway smooth muscle; BV, blood vessel; CysLT1RA, cysteinyl leukotriene receptor 1 antagonist; EOS, eosinophils; GPR35, G-protein-coupled receptor 35; H1R, histamine H1 receptor; Histamine RA, histamine receptor antagonist; ILC2, type 2 innate lymphoid cells; KC, keratinocytes; LA, lysosomotropic agent; LTC4, leukotriene C4; MC, mast cell; N, neuron; PD2RA, prostaglandin D2 receptor 2 antagonist; PGD2, prostaglandin D2; PI3K, phosphatidylinositol 3-kinase; SCG, sodium cromoglicate (denotes inhibition). ${ }^{*}$ Denotes regimens that are in current clinical use for intervention with MC-related activities.

\section{Approaches Aimed at Inhibiting MC-Derived Mediators or Their Effects}

Given that MCs are capable of releasing a large array of diverse biologically active mediators, one possible therapeutic option is to target individual MC mediators. For example, several MC mediators such as histamine, leukotrienes, prostaglandins, and cytokines are currently targeted effectively by available drugs [4] (Fig. 2). Moreover, multiple MC-specific proteases, for example, chymase and tryptase can be selectively inhibited [73-76]. Targeting any given MC mediator can be achieved either by direct inhibition of the mediator, for example, when the enzymatic activities of MC proteases are blocked by active site-directed inhibitors, or when neutralizing antibodies are used. Alternatively, downstream effects of MC-released compounds can be targeted by employing antagonists of receptors for compounds released by activated MCs.

Drugs that target histamine (e.g., ketotifen), leukotrienes (e.g., montelukast), and PGD2 (e.g., fevipiprant) represent receptor antagonists (Fig. 2), and these drugs are known to reduce symptoms of allergies and related disorders such as asthma in clinical settings [77-80]. Further, MC-produced proinflammatory cytokines and growth factors, such as TNF- $\alpha$, IL-4, IL-13, IL-17, and VEGF, can be targeted by neutralizing antibodies. Although the latter proinflammatory cytokines/growth factors are not exclusively produced by MCs, MCs are known to be a dominant source of these compounds in several pathological settings [81]. For example, it has been proposed that MCs are the predominant source of IL-17 in patients with inflammatory skin and joint diseases including psoriasis [82], rheumatoid arthritis [83], and spondyloarthritis $[84,85]$. Notably, monoclonal antibodies directed to IL-17 (Fig. 2) are currently being evaluated for efficacy in such conditions [86], and it is thus conceivable that anti-IL-17 therapy, at least to some extent, acts at the level of neutralizing IL-17 released from MCs.

Other MC-derived cytokines that constitute therapeutic targets include IL-4 and IL-13. These two cytokines play key roles in promoting several hallmark features of Th2 inflammation, including IgE production, smooth muscle contractility, mucus production, and inflammatory cell recruitment to the inflammation site [87-89]. In asthma patients, MCs were found to produce IL-4 [67], and IL- 4 is also found as a preformed meditator stored in MC granules [90]. Furthermore, IL-4- and IL-13-expressing MCs accumulate within the airway smooth muscle layer of asthmatics, suggesting a role for these cytokines in MC:airway smooth muscle interactions [91]. MCs also produce IL-13 in response to various stimuli including IgE/antigen, IL-1 $\beta$, IL-4, IL-33, LPS, and peptidoglycan [92-97]. Dupilumab is a monoclonal antibody directed against the a subunit of the IL- 4 receptor (IL-4R $\alpha$ ) that blocks signal transduction pathways activated by IL- 4 and IL-13 (Fig. 2). Of note, dupilumab has shown striking beneficial effects in improving several disease features in patients suffering from MC-associated allergic conditions such as asthma $[98,99]$ and atopic dermatitis $[100$ 102].

Although targeting of individual MC mediators can have anti-inflammatory effects, the beneficial therapeutic effects of such treatments are often limited [81]. One major reason for this could be that the overall impact of MCs in a pathological setting is most likely a result of combined effects from several MC mediators, rather than due 
to a single mediator acting on a single target [4]. Thus, targeting a single MC mediator will only partly interfere with detrimental MC effects. As an example, targeting only IL-13 by lebrikizumab or tralokinumab in asthma has shown a very limited beneficial effect, whereas targeting both IL- 4 and IL-13 by dupilumab effectively improved lung function and symptoms [103]. Similarly, therapeutic regimens that include using a combination of leukotrienes and histamine antagonists were found to have greater beneficial effects on improving allergen-induced airway obstruction in asthmatics compared to those achieved by each drug alone [104-106]. Altogether, based on these clinical observations, in order to achieve efficient therapeutic effects, this class of anti-MC drugs (i.e., $\mathrm{MC}$ mediator targeting drugs) are required to be used in combination and often recommended as add-on therapy to inhaled corticosteroids $[79,107]$.

\section{Approaches Aimed at Inhibiting MC Activation}

Considering that MCs express a large number of activating and inhibitory receptors (Table 2), one option is to block MC activation by using drugs that interfere with such receptors. One approach to accomplish this is to use monoclonal antibodies to target IgE, thereby blocking the interaction of IgE with its high-affinity receptor (FceRI) (Fig. 2). One such monoclonal antibody is omalizumab, a humanized IgG1 antibody against IgE. Omalizumab is approved for clinical use and was found to reduce asthma symptoms in adults and children [81, 108, 109]. Moreover, beneficial therapeutic effects of omalizumab have been observed in persistent allergic rhinitis [110], atopic dermatitis [111], urticaria [112, 113], and food allergies [114].

Although anti-IgE therapy represents a successful approach to inhibit MC activation, there are several disadvantages that limit its use. For example, anti-IgE therapy is beneficial in treatment of allergic disorders but has very limited efficacy, if any, in the treatment of non-allergic MC-driven diseases, in which MCs are activated by IgEindependent pathways [4]. Another limitation is its unpredictable efficacy, that is, some asthmatic patients show considerable improvement, whereas most patients experience little or no signs of clinical improvement [115]. Additionally, similar to other treatments that involve the use of humanized monoclonal antibodies, anti-IgE therapy is associated with high economic costs [81].

Another group of compounds that display inhibitory effects on MC activation are the MC stabilizers, which have the ability to inhibit MC degranulation and mediator release in response to various stimuli [116]. Sodium cromoglycate (SCG) and nedocromil sodium are the most common MC stabilizers used for treating asthma and other diseases that involve MC activation, including allergic rhinitis, allergic conjunctivitis, atopic dermatitis, and mastocytosis [31]. Despite being in clinical use for decades, the mechanisms by which these drugs inhibit MC activation and degranulation are still not well-defined [4]. However, it has become more evident during the recent years that the effects of SCG and nedocromil sodium are mediated via GPR35, an inhibitory MC receptor [117] (Fig. 2).

Although MC stabilizers are generally well-tolerated, their inhibitory effects are moderate or negligible [4]. In fact, comparative studies suggest that the beneficial effect of SCG in controlling asthma symptoms is rather small in both children and adults $[118,119]$. One possible reason for this could be that MC stabilizers do not inhibit human lung MCs effectively. In support of this notion, SCG has been found to be a weak inhibitor of histamine release from freshly isolated human lung MCs in response to IgE-mediated activation, even when high concentrations of SCG were used [120]. Another disadvantage of the MC stabilizers is that, due to their low potency and short halflife, high concentrations of the drugs need to be given at frequent intervals to have an effective inhibitory impact. Moreover, local administrations are preferred to maximize the concentration of the drug in the target tissue [116].

An alternative approach to inhibit $\mathrm{MC}$ activation is to interfere with the intracellular signalling pathways that are essential for MC degranulation and mediator release $[4,81,121]$. This can be achieved, for example, by using pharmacologic inhibitors to block the function of key cytoplasmic signalling proteins such as spleen tyrosine kinase (SYK), phosphatidylinositol 3-kinases, and Bruton's tyrosine kinase. Since these proteins are involved in early signalling events induced by IgE:FceRI interaction, their inhibition could theoretically result in effective suppression of antigen-induced degranulation and mediator release [4]. In line with this, several inhibitors of the aforementioned signalling proteins exhibited beneficial effects when tested in preclinical in vivo models. For example, IC87114, a selective inhibitor of phosphatidylinositol 3 -kinase- $\delta$, was found to have a therapeutic potential for the treatment of allergic asthma and rheumatoid arthritis in the relevant disease models [122, 123] (Fig. 2). Furthermore, a number of different inhibitors are being tested in clinical trials for diseases such as allergic rhinitis, asthma, 
urticaria, and rheumatoid arthritis $[4,81]$. Although some of these inhibitors have been able to reduce certain disease symptoms in patients during initial phases of clinical trials, so far none of them have been approved for routine treatment of MC-related diseases [4]. For example, the SYK inhibitors, R112 and R343, both failed in clinical phase II studies for treatment of allergic rhinitis or asthma [81]. Another potential strategy for inhibition of MC activation is to target various ion channels involved in the signalling pathways leading to MC activation/degranulation, as exemplified by the Orai channels [124].

One major problem with approaches targeting signalling pathways is that they are not exclusive to MCs. Indeed, the fact that the signalling proteins are widely expressed by many different cell types gives rise to an increased risk of adverse effects when inhibitors of signalling protein are used [4]. Moreover, the majority of inhibitors that are available or being considered for clinical development, are directed against signalling pathways that operate downstream of classical IgE-mediated MC activation [23]. Thus, they predominantly suppress MC activation in allergic settings where MCs are activated by IgE-mediated stimulation, but have limited effectiveness in situations in which MCs are activated through other mechanisms [23].

\section{Approaches Aimed at Reducing MC Numbers}

The overall impact of MCs on any pathological setting is most likely multifaceted, that is, mediated by multiple activating mechanisms and a large number of secreted mediators. Thus, targeting individual mediators or single activation pathways in MCs, for example the IgE-mediated pathway, may not be sufficient to prevent the full panel of MC-driven pathological effects. Theoretically, a more effective strategy for global inhibition of harmful MC activities might therefore be to reduce $\mathrm{MC}$ numbers, for example, by blocking MC survival or inducing their apoptosis $[81,125,126]$. However, in order to avoid harmful side effects that may arise from off-targeting of other cell populations, it is essential to develop strategies that are selective for MCs. In the following section, the major strategies that can be employed for reducing $\mathrm{MC}$ survival or inducing $\mathrm{MC}$ apoptosis are discussed.

\section{Strategies to Reduce MC Survival}

Mature MCs depend on stem cell factor (SCF) for their survival [16], and targeting of SCF signalling thereby rep- resents an attractive strategy for limiting MC survival. The interaction between SCF and its receptor, c-kit (CD117), which has tyrosine kinase activity [127], induces intracellular signalling that promotes MC differentiation, proliferation, chemotaxis, and maturation [16]. The pivotal role of SCF for MC survival and development is highlighted by the finding that mice deficient in SCF or c-kit essentially lack MCs [14, 128, 129]. Moreover, glucocorticoid-induced reduction of local SCF levels results in decreased numbers of tissue MCs in mice [130], and corticosteroids can also reduce the MC numbers in humans [131, 132]. Additionally, administration of SCF to humans, baboons, cynomolgus monkeys, mice, and rats promotes in vivo expansion of tissue MCs [133-135]. The ability of the SCF:c-kit axis to induce MC survival appears to be mediated, at least partly, through downregulation of pro-apoptotic proteins such as Bim [136].

It is thought that SCF and c-kit contribute to the MC accumulation and survival in MC-driven disorders. For example, in humans, gain-of-function mutations in c-kit lead to mastocytosis, a disorder characterized by an expansion of MC populations, due to constitutive SCF-independent activation of c-kit [137]. Furthermore, in individuals with various allergic diseases including asthma, allergic rhinitis, and atopic dermatitis, an increased production of SCF [138-142] and elevated MC numbers are commonly seen [143]. It is also known that increased SCF levels correlate with disease severity in patients with asthma or atopic dermatitis $[139,142]$.

Based on these findings, blockade of MC survival and development through inhibition of the SCF:c-kit axis has been considered as a potential treatment option to decrease MC numbers in certain pathological conditions [4] (Fig. 2). Imatinib is an inhibitor that is known to target c-kit and other tyrosine kinases. It was initially developed for targeting BCR-ABL (breakpoint cluster region-Abelson murine leukaemia viral oncogene homologue 1) in patients with chronic myeloid leukaemia but has also been shown to reduce MC numbers in endobronchial biopsy samples and to reduce serum tryptase levels and AHR in patients with severe asthma [144]. Moreover, imatinib is now approved for the treatment of adult patients with aggressive systemic mastocytosis in cases lacking the KitD816V mutation [145]; notably, in a phase IV clinical trial, imatinib caused a reduction of MC numbers in mastocytosis patients that had Kit mutations other than KitD816V [146]. In addition to imatinib, several other tyrosine kinase inhibitors including nilotinib, dasatinib, midostaurin, and masitinib are being evaluated for efficacy in several MC-driven diseases [81]. However, 
none of these inhibitors are specific for c-kit, that is, they are capable of inhibiting multiple other tyrosine kinases [81]. Thus, the effects of available tyrosine kinase inhibitors extend far beyond MCs, resulting in a high risk of off-target effects on non-MC populations.

\section{Strategies to Induce MC Apoptosis}

Historically, cell death has been classified into two major forms: apoptosis and necrosis [147]. Apoptosis is a highly regulated mode of cell death and plays an essential role in development, morphogenesis, and maintaining homoeostasis through the removal of damaged, aged, and potentially dangerous cells [148]. Apoptosis is initiated by the activation of caspases, leading to cell shrinking, chromatin condensation, DNA fragmentation, plasma membrane blebbing, and formation of apoptotic bodies [149-151]. In contrast, necrosis is a less controlled cell death mode characterized by loss of cell membrane integrity and release of numerous cellular contents, such as danger signals, into the extracellular environment. Therefore, unlike apoptosis, necrosis can potentially induce an inflammatory response [147]. Apoptotic cell death can be induced via two major classical pathways: the intrinsic and extrinsic pathways [151]. The intrinsic pathway is initiated in response to cell stress stimuli such as DNA damage, oxidative stress, growth factor deprivation, and cytotoxic substances through activating pro-apoptotic proteins (e.g., BH3-only proteins) [152-154]. Once activated, these proteins inhibit anti-apoptotic proteins (e.g., Bcl-2 and Bcl-XL) leading to mitochondrial outer membrane permeabilization. This results in release of apoptogenic factors such as cytochrome $\mathrm{c}$ and apoptosis-inducing factor that can execute apoptotic cell death through caspase-dependent and/or caspase-independent mechanisms $[151,155]$. The extrinsic pathway of apoptosis is triggered when cell surface death receptors bind to their ligands [156]. The death receptors include tumour necrosis factor receptor (TNFR), Fas, and TNF-related apoptosis-inducing ligand receptor (TRAIL-R), which all belong to the TNFR superfamily [157]. Interaction of the death receptors with their cognate ligands, that is, TNF, FasL, and TRAIL, provokes the intracellular assembly of a multiprotein complex known as death-inducing signalling complex and recruitment of adaptor proteins. This, in turn, leads to caspase activation and apoptosis [154, 156].

In addition to these classical pathways for initiating apoptotic cell death, it has been revealed that apoptosis can be caused by lysosome membrane permeabilization, which can occur in response to various triggers, including chemical compounds with lysosome membrane-permea- bilizing properties ("lysosomotropic agents"). In this process, lysosomal enzymes such as various cysteine cathepsins escape from the lysosomes to the cytosolic compartment, where they cause apoptosis by proteolytic activation of pro-apoptotic compounds and/or degradation of antiapoptotic proteins [154, 158-161].

The concept of selectively inducing $\mathrm{MC}$ apoptosis as a means to intervene with MC-driven diseases is emerging as an attractive therapeutic approach [125]. To achieve MC apoptosis, one strategy could be to activate pro-apoptotic pathways, for example, by using agonists of surface death receptors (e.g., TRAIL-R). Currently, several TRAIL-R agonists are being tested in preclinical and clinical studies for their therapeutic beneficial effects in different cancers [162]. However, although human MCs express TRAIL-R and were found to undergo apoptosis through engagement by TRAIL [163], the selectivity of TRAIL-mediated apoptosis for MCs is questionable. This is due to the fact TRAIL-R is widely expressed among many human tissues and cell types $[162,164$, 165].

Another approach to induce MC apoptosis would be to interfere with the function of anti-apoptotic proteins. In line with this scenario, small molecule compounds known as $\mathrm{BH} 3$ mimetics were found to induce apoptosis in MCs through inhibiting the effect of anti-apoptotic proteins such as Bcl-2, Bcl-XL, and Mcl-1 [166-168]. However, due to the ubiquitous expression of these antiapoptotic proteins, such compounds are not likely to act selectively on MCs. In line with this notion, the $\mathrm{BH} 3 \mathrm{mi}$ metic ABT-737 was shown to induce apoptosis in MCs (Fig. 2) but also in a variety of other cell types, including B lymphocytes, neuronal cells, and transformed cells of various origin $[166,169,170]$. Due to differences in their chemical structures and properties, various $\mathrm{BH} 3$ mimetic compounds can target individual anti-apoptotic proteins [168]. On the other hand, different MC types were found to express distinct levels of individual anti-apoptotic proteins, which results in differential sensitivities toward a certain BH3 mimetic compound [166]. For example, MCs with lower expression of Mcl-1 and higher expression of $\mathrm{Bcl}-2$ are more sensitive to apoptosis induced by ABT-737, whereas MCs with an opposite expression profile of Mcl-1 and Bcl-2 were more resistant [166]. These findings suggest that in order to execute efficient MC apoptosis by $\mathrm{BH} 3$ mimetic compounds, a combination of several different compounds is likely required. This, in turn, increases the risk of causing apoptosis in cell types other than MCs, potentially resulting in adverse side effects. 
Induction of MC Death by Granule Permeabilization

Given that most pro-apoptotic pathways are ubiquitously present among different cell types, it has been challenging to identify a cell death pathway that is selective to MCs. If a pro-apoptotic strategy is to be selective for MCs, it must be established based on their unique properties. This could potentially be accomplished by targeting MCspecific cell surface receptors, a strategy that was recently utilized by inducing MC death via the MRGPRX2 receptor [171]. Targeting MCs via c-kit (receptor for SCF) could also be an option (see "Strategies to reduce MC survival"). Another unique feature of MCs is their abundant cytoplasmic secretory granules. The granules contain exceptionally large amounts of various bioactive compounds, including proteases $[19,75,76]$. Conceptually, the escape of such proteases into the cytosolic compartment could cause apoptosis by proteolytic activation of pro-apoptotic compounds and/or degradation of antiapoptotic proteins.

Interestingly, MC granules have striking similarities with lysosomes and are therefore also denoted "secretory lysosomes" [172]. For example, both compartments have an acidic $\mathrm{pH}$, similar membrane composition and contain typical lysosomal enzymes such as cysteine- and aspartic acid cathepsins, arylsulfatase $A, \beta$-glucuronidase, and $\beta$-hexosaminidase $[19,172,173]$. Based on such similarities, it is reasonable to assume that compounds capable of inducing lysosome permeabilization, that is, "lysosomotropic agents" (see under "Strategies to induce MC apoptosis"), also cause granule permeabilization in MCs. This would cause the release of potent granule enzymes, for example, proteases, into the cytosol where they potentially may induce apoptosis. Moreover, since MCs have a much higher content of protease-rich granules than any other cell type in the body, it is conceivable that strategies to induce apoptosis through granule permeabilization could be selectively cytotoxic for MCs. In support of this notion, it was shown that the prototype lysosomotropic agent L-leucyl-L-leucine methyl ester (LLME) induces apoptosis in murine cultured MCs by causing permeabilization of the granule membrane (Fig. 2) [174]. Moreover, it was demonstrated that LLME showed selectivity for MCs versus several other cell types $[175,176]$.

Interestingly, mouse MCs lacking serglycin were considerably less sensitive to LLME than were wild-type (WT) cells [174]. Since serglycin is restricted to the secretory granules of MCs [177], this finding thus provides strong support for an involvement of the secretory granules in the cell death responses towards LLME. It was also noted that the type of cell death differed dramatically in
WT versus serglycin ${ }^{-/}$MCs, with WT cells undergoing apoptosis whereas the serglycin ${ }^{-/}$cells died preferentially by necrosis [178]. Since serglycin acts as a scaffold for the storage of several potent proteases [177], a likely explanation for these findings might be that the apoptosis-promoting effect of serglycin is due to downstream effects of any of the proteases that are dependent on serglycin for storage, rather than through direct apoptosis-promoting functions of serglycin. Indeed, it was shown that the absence of Mcpt6 (a serglycin-dependent protease [177]) phenocopied the effects of serglycin-deficiency in terms of effects on apoptosis/necrosis [178].

These findings suggest that MCs are highly sensitive to cell death induced by granule permeabilization caused by lysosomotropic agents, introducing the possibility of evaluating lysosomotropic agents as potential therapeutics to selectively deplete harmful MC populations. However, LLME is not approved for usage in vivo in humans, and it has therefore been important to identify lysosomotropic agents that are more readily adaptable for clinical purposes. One such candidate is siramesine. Siramesine was originally developed as a sigma-2 agonist for treatment of anxiety [179]. It was reported to be safe for use in humans but was inefficient for the intended purpose. On the other hand, it was later shown that it possessed lysosomotropic activity on certain cancer cell types [180], and it was therefore reasoned that it could have the ability to induce secretory granule permeabilization and cell death also in MCs. Indeed, it was shown that siramesine potently induced apoptotic cell death in MCs [181]. Moreover, it was shown that siramesine selectively depleted MC populations, both in vivo in mouse models and in human ex vivo settings $[176,181,182]$.

In further attempts to identify lysosomotropic agents with optimal cytotoxic effects on MCs, it was shown that mefloquine, an approved anti-malaria drug, was strongly cytotoxic for both mouse and human MCs, causing apoptotic cell death [183]. As for LLME and siramesine, mefloquine was shown to cause membrane permeabilization in various types of MCs, leading to apoptotic cell death. Further, it was shown that mefloquine-induced cell death was dependent on ROS [183]. It was also demonstrated that mefloquine, similar to siramesine, shows selective cytotoxic effects on MCs $[183,184]$. In attempts to further clarify the mechanism by which mefloquine induces MC death, it was revealed that the ROS production in response to mefloquine occurs in the secretory granules, and that the ROS production was dependent on iron bound to serglycin present in granules. ROS production was also partially dependent on granzyme B, and it was 


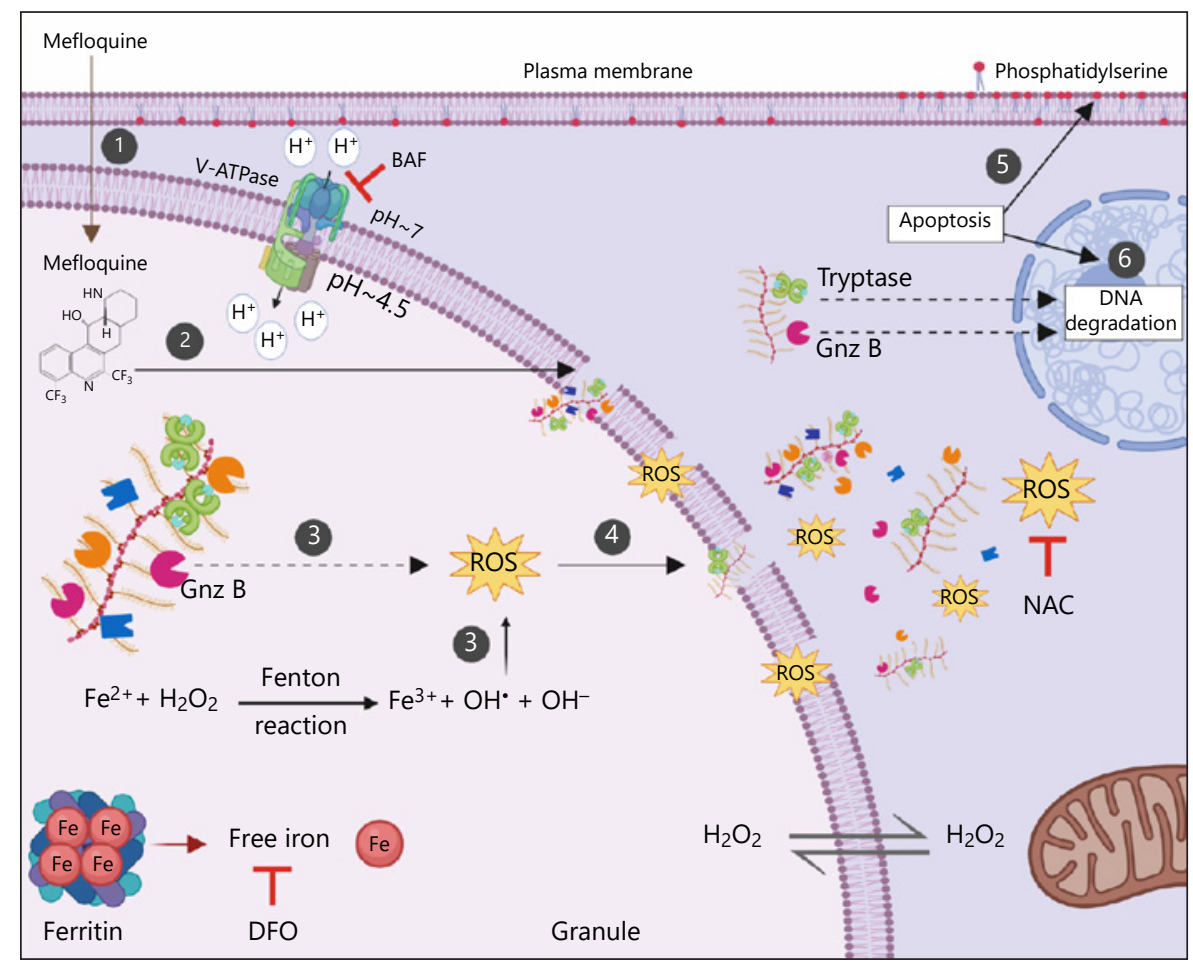

Fig. 3. Suggested mechanism by which lysosomotropic agents (here exemplified by mefloquine) induce granule membrane permeabilization and apoptosis in MCs. (1) Accumulation of mefloquine inside the granules. Mefloquine, a weakly basic compound, can in its unprotonated form passively diffuse through the MC plasma and granule membranes. In the acidic interior of granules, mefloquine becomes protonated and can no longer pass through the membrane, thus accumulating inside the granules. (2) Granule membrane permeabilization. When the mefloquine concentration reaches a certain threshold, mefloquine acquires detergent-like properties and induces granule membrane damage and permeabilization. (3) Induction of oxidative stress within granules. Hydrogen peroxide $\left(\mathrm{H}_{2} \mathrm{O}_{2}\right)$ freely diffuses into the granules. In the granules, the acidic $\mathrm{pH}$ and the presence of free iron promote the oxidation of iron and the generation of ROS such as hydroxyl radicals $\left(\mathrm{HO}^{*}\right)$ via Fenton-type reactions. The electrostatic interaction between negatively charged serglycin and cationic iron likely par-

shown that the cytotoxic effects of mefloquine on MCs were strictly dependent on an acidic $\mathrm{pH}$ in the granules [185]. A proposed model for how lysosomotropic agents can promote MC apoptosis is depicted in Figure 3. Importantly, since mefloquine is an approved drug for usage in humans, it may be relatively feasible to adapt it for clinical purposes under circumstances where selective depletion of MCs may have a therapeutic potential. ticipates in maintaining the iron pool within MC granules, thus contributing to the generation of ROS. The generated ROS cause further destabilization of granule membranes leading to the release of many granule components into the cytosol. Granzyme B also participates in induction of ROS production upon exposure to mefloquine. (4) Release of granule contents into the cytosol. Due to the granule permeabilization, granule contents (e.g., fully active proteases in complex with serglycin, ROS and iron) enter the cytosol. $(5,6)$ Induction of apoptosis. Mefloquine-induced granule permeabilization and the subsequent translocation of the granule contents to the cytosol induce apoptosis manifested by phosphatidylserine externalization and DNA degradation. The MC proteases, such as tryptase and granzyme B, may participate in apoptosis in response to mefloquine. BAF, bafilomycin-A1; DFO, deferoxamine mesylate; Gnz B, granzyme B; NAC, $\mathrm{N}$-acetylcysteine; ROS, reactive oxygen species.

\section{Concluding Remarks and Future Perspectives}

The current consensus is that MCs contribute importantly to the manifestations of many debilitating human diseases including asthma, and there is therefore a current demand for strategies to block or dampen their harmful effects. As described here, multiple regimes to accomplish this have been developed or are under development, and many such strategies are currently being exploited in the clinic. However, it is important to empha- 
size that MCs from different species and from different tissues show considerable heterogeneity in terms of gene expression profile, granular content and morphological criteria. Thereby, an important consideration is that MCs of different phenotype can be differently sensitive to individual treatment options. This issue certainly warrants further investigations to firmly establish the applicability of the various available anti-MC therapies. Another general consideration is that most of the currently available strategies to limit MC activities are not MC-selective. For example, the pathogenic cytokines secreted by MCs are also expressed by multiple other cell types, and their targeting will thus not selectively interfere with MC-dependent effects of the corresponding cytokines/chemokines. Further, compounds known as "MC stabilizers" show only moderate selectivity for MCs, and anti-IgE therapy will target, not only MCs, but also other cells expressing FceRI (e.g., basophils). Hence, effects seen for such therapeutic regimens may not be exclusively due to effects on the MC niche, which may affect the interpretation of the data as to whether MCs play a prominent role in the respective condition. In other strategies, MCs are targeted with a higher extent of selectivity, as exemplified by strategies targeting MC-restricted mediators such as chymase and tryptase. In addition, an emerging concept is to selectively induce MC apoptosis, at least locally. As described herein, there are multiple emerging strategies for the latter purpose, although these efforts are still at the pre-clinical stage. We foresee that such strategies will be devel- oped in the future, and will aid in our attempts to therapeutically intervene with the detrimental impact of MCs in human diseases.

\section{Acknowledgement}

The figures were prepared using BioRender.com.

\section{Conflict of Interest Statement}

The authors report no conflict of interest in relation to this work.

\section{Funding Sources}

The authors of this article receive funds from the Swedish Research Council (GP), The Swedish Cancer Foundation (GP), The Swedish Heart and Lung Foundation (GP), The Swedish Child Cancer Foundation (GP), The Knut and Alice Wallenberg Foundation (GP). Neither of the sponsors had any input on the contents of this article.

\section{Author Contributions}

A.P. and G.P. conceived of this article; A.P. prepared the illustrations; A.P. drafted the manuscript; G.P. contributed to the writing of the article.

\section{References}

1 Metcalfe DD, Baram D, Mekori YA. Mast cells. Physiol Rev. 1997 Oct;77(4):1033-79.

2 Galli SJ, Nakae S, Tsai M. Mast cells in the development of adaptive immune responses. Nat Immunol. 2005 Feb;6(2):135-42.

3 Voehringer D. Protective and pathological roles of mast cells and basophils. Nat Rev Immunol. 2013 May;13(5):362-75.

4 Siebenhaar F, Redegeld FA, Bischoff SC, Gibbs BF, Maurer M. Mast cells as drivers of disease and therapeutic targets. Trends Immunol. 2018 Feb;39(2):151-62.

5 Galli SJ, Gaudenzio N, Tsai M. Mast cells in inflammation and disease: recent progress and ongoing concerns. Annu Rev Immunol. 2020 Apr 26;38:49-77.

6 Marshall JS. Mast-cell responses to pathogens. Nat Rev Immunol. 2004 Oct;4(10):78799.

7 Abraham SN, St John AL. Mast cell-orchestrated immunity to pathogens. Nat Rev Immunol. 2010 Jun;10(6):440-52.
8 Johnzon CF, Rönnberg E, Pejler G. The role of mast cells in bacterial infection. Am J Pathol. 2016 Jan;186(1):4-14.

9 Marshall JS, Portales-Cervantes L, Leong E. Mast cell responses to viruses and pathogen products. Int J Mol Sci. 2019 Aug 30;20(17): 4241.

10 Galli SJ, Tsai M. IgE and mast cells in allergic disease. Nat Med. 2012 May 4;18(5):693-704.

11 Bradding P, Pejler G. The controversial role of mast cells in fibrosis. Immunol Rev. 2018 Mar;282(1):198-231.

12 Elieh Ali Komi D, Bjermer L. Mast cell-mediated orchestration of the immune responses in human allergic asthma: current insights. Clin Rev Allergy Immunol. 2019 Apr;56(2): 234-47.

13 Kitamura Y, Shimada M, Hatanaka K, Miyano Y. Development of mast cells from grafted bone marrow cells in irradiated mice. Nature. 1977 Aug 4;268(5619):442-3.
14 Kitamura Y, Go S, Hatanaka K. Decrease of mast cells in W/Wv mice and their increase by bone marrow transplantation. Blood. 1978 Aug;52(2):447-52.

15 Gurish MF, Austen KF. Developmental origin and functional specialization of mast cell subsets. Immunity. 2012 Jul 27;37(1):25-33.

16 da Silva EZ, Jamur MC, Oliver C. Mast cell function: a new vision of an old cell. J Histochem Cytochem. 2014 Oct;62(10):698-738.

17 Reber LL, Sibilano R, Mukai K, Galli SJ. Potential effector and immunoregulatory functions of mast cells in mucosal immunity. Mucosal Immunol. 2015 May;8(3):44463.

18 Gentek R, Ghigo C, Hoeffel G, Bulle MJ, Msallam R, Gautier G, et al. Hemogenic endothelial fate mapping reveals dual developmental origin of mast cells. Immunity. 2018 Jun 19;48(6):1160-e5.

19 Wernersson S, Pejler G. Mast cell secretory granules: armed for battle. Nat Rev Immunol. 2014 Jul;14(7):478-94. 
20 Mukai K, Tsai M, Saito H, Galli SJ. Mast cells as sources of cytokines, chemokines, and growth factors. Immunol Rev. 2018 Mar; 282(1):121-50.

21 Urb M, Sheppard DC. The role of mast cells in the defence against pathogens. PLoS Pathog. 2012;8(4):e1002619.

22 Rao KN, Brown MA. Mast cells: multifaceted immune cells with diverse roles in health and disease. Ann N Y Acad Sci. 2008 Nov;1143: 83-104.

23 Bradding P, Arthur G. Mast cells in asthma: state of the art. Clin Exp Allergy. 2016 Feb; 46(2):194-263.

24 Metz M, Piliponsky AM, Chen CC, Lammel V, Abrink M, Pejler G, et al. Mast cells can enhance resistance to snake and honeybee venoms. Science. 2006 Jul 28;313(5786):52630.

25 Schneider LA, Schlenner SM, Feyerabend TB, Wunderlin M, Rodewald HR. Molecular mechanism of mast cell mediated innate defense against endothelin and snake venom sarafotoxin. J Exp Med. 2007 Oct 29;204(11): 2629-39.

26 Akahoshi M, Song CH, Piliponsky AM, Metz M, Guzzetta A, Abrink M, et al. Mast cell chymase reduces the toxicity of Gila monster venom, scorpion venom, and vasoactive intestinal polypeptide in mice. J Clin Invest. 2011 Oct;121(10):4180-91.

27 Shimokawa C, Kanaya T, Hachisuka M, Ishiwata $\mathrm{K}$, Hisaeda $\mathrm{H}$, Kurashima $\mathrm{Y}$, et al. Mast cells are crucial for induction of group 2 innate lymphoid cells and clearance of helminth infections. Immunity. 2017 May 16;46(5): 863-e4.

28 Varricchi G, de Paulis A, Marone G, Galli SJ. Future needs in mast cell biology. Int J Mol Sci. 2019 Sep 6;20(18):4397.

29 Galli SJ, Tsai M, Piliponsky AM. The development of allergic inflammation. Nature. 2008 Jul 24;454(7203):445-54.

30 Brown MA, Hatfield JK. Mast cells are important modifiers of autoimmune disease: with so much evidence, why is there still controversy? Front Immunol. 2012;3:147.

31 Reber LL, Frossard N. Targeting mast cells in inflammatory diseases. Pharmacol Ther. 2014 Jun;142(3):416-35.

32 Varricchi G, Galdiero MR, Loffredo S, Marone $\mathrm{G}$, Iannone R, Marone $\mathrm{G}$, et al. Are mast cells MASTers in cancer? Front Immunol. 2017;8:424.

33 Cookson H, Grattan C. An update on mast cell disorders. Clin Med. 2016 Dec;16(6):5803.

34 Onnes MC, Tanno LK, Elberink JNJN. Mast cell clonal disorders: classification, diagnosis and management. Curr Treat Options Allergy. 2016;3(4):453-64.

35 Elberink RE, Cataldo D, Buckley MG, Sele J, Henket M, Lau LC, et al. Evidence of mast-cell activation in a subset of patients with eosinophilic chronic obstructive pulmonary disease. Eur Respir J. 2002 Aug;20(2):325-31.
36 Andersson CK, Mori M, Bjermer L, Löfdahl CG, Erjefält JS. Alterations in lung mast cell populations in patients with chronic obstructive pulmonary disease. Am J Respir Crit Care Med. 2010 Feb 1;181(3):206-17.

37 Bot I, Shi GP, Kovanen PT. Mast cells as effectors in atherosclerosis. Arterioscler Thromb Vasc Biol. 2015 Feb;35(2):265-71.

38 Brightling CE, Bradding P, Symon FA, Holgate ST, Wardlaw AJ, Pavord ID. Mast-cell infiltration of airway smooth muscle in asthma. N Engl J Med. 2002 May 30;346(22): 1699-705.

39 Dougherty RH, Sidhu SS, Raman K, Solon M, Solberg OD, Caughey GH, et al. Accumulation of intraepithelial mast cells with a unique protease phenotype in $\mathrm{T}(\mathrm{H}) 2$-high asthma. J Allergy Clin Immunol. 2010 May; 125(5): 1046-e8.

40 Andersson CK, Bergqvist A, Mori M, Mauad T, Bjermer L, Erjefält JS. Mast cell-associated alveolar inflammation in patients with atopic uncontrolled asthma. J Allergy Clin Immunol. 2011 Apr;127(4):905-7.

41 Carroll NG, Mutavdzic S, James AL. Distribution and degranulation of airway mast cells in normal and asthmatic subjects. Eur Respir J. 2002 May; 19(5):879-85.

42 Amin K, Lúdvíksdóttir D, Janson C, Nettelbladt O, Björnsson E, Roomans GM, et al. Inflammation and structural changes in the airways of patients with atopic and nonatopic asthma. BHR Group. Am J Respir Crit Care Med. 2000 Dec;162(6):2295-301.

43 Balzar S, Chu HW, Strand M, Wenzel S. Relationship of small airway chymase-positive mast cells and lung function in severe asthma. Am J Respir Crit Care Med. 2005 Mar 1; 171(5):431-9.

44 Carroll NG, Mutavdzic S, James AL. Increased mast cells and neutrophils in submucosal mucous glands and mucus plugging in patients with asthma. Thorax. 2002 Aug; 57(8):677-82.

45 Mendez-Enriquez E, Hallgren J. Mast cells and their progenitors in allergic asthma. Front Immunol. 2019;10:821.

46 Williams CM, Galli SJ. Mast cells can amplify airway reactivity and features of chronic inflammation in an asthma model in mice. J Exp Med. 2000 Aug 7;192(3):455-62.

47 Yu M, Tsai M, Tam SY, Jones C, Zehnder J, Galli SJ. Mast cells can promote the development of multiple features of chronic asthma in mice. J Clin Invest. 2006 Jun;116(6):163341.

48 Sawaguchi M, Tanaka S, Nakatani Y, Harada Y, Mukai K, Matsunaga Y, et al. Role of mast cells and basophils in IgE responses and in allergic airway hyperresponsiveness. J Immunol. 2012 Feb 15;188(4):1809-18.

49 Murray JJ, Tonnel AB, Brash AR, Roberts LJ 2nd, Gosset P, Workman R, et al. Release of prostaglandin D2 into human airways during acute antigen challenge. N Engl J Med. 1986 Sep 25;315(13):800-4.
50 Schleimer RP, MacGlashan DW Jr, Peters SP, Pinckard RN, Adkinson NF Jr, Lichtenstein LM. Characterization of inflammatory mediator release from purified human lung mast cells. Am Rev Respir Dis. 1986 Apr;133(4): 614-7.

51 Casale TB, Wood D, Richerson HB, Zehr B, Zavala D, Hunninghake GW. Direct evidence of a role for mast cells in the pathogenesis of antigen-induced bronchoconstriction. J Clin Invest. 1987 Nov;80(5):1507-11

52 Wenzel SE, Fowler AA 3rd, Schwartz LB. Activation of pulmonary mast cells by bronchoalveolar allergen challenge. In vivo release of histamine and tryptase in atopic subjects with and without asthma. Am Rev Respir Dis. 1988 May; 137(5):1002-8.

53 Wenzel SE, Larsen GL, Johnston K, Voelkel NF, Westcott JY. Elevated levels of leukotriene $\mathrm{C} 4$ in bronchoalveolar lavage fluid from atopic asthmatics after endobronchial allergen challenge. Am Rev Respir Dis. 1990 Jul; 142(1):112-9.

54 Liu MC, Hubbard WC, Proud D, Stealey BA, Galli SJ, Kagey-Sobotka A, et al. Immediate and late inflammatory responses to ragweed antigen challenge of the peripheral airways in allergic asthmatics. Cellular, mediator, and permeability changes. Am Rev Respir Dis. $1991 \mathrm{Jul} ; 144(1): 51-8$.

55 Sedgwick JB, Calhoun WJ, Gleich GJ, Kita H, Abrams JS, Schwartz LB, et al. Immediate and late airway response of allergic rhinitis patients to segmental antigen challenge. Characterization of eosinophil and mast cell mediators. Am Rev Respir Dis. 1991 Dec;144(6): 1274-81

56 Wenzel SE, Westcott JY, Larsen GL. Bronchoalveolar lavage fluid mediator levels 5 minutes after allergen challenge in atopic subjects with asthma: relationship to the development of late asthmatic responses. J Allergy Clin Immunol. 1991 Feb;87(2):540-8.

57 Curzen N, Rafferty P, Holgate ST. Effects of a cyclo-oxygenase inhibitor, flurbiprofen, and an $\mathrm{H} 1$ histamine receptor antagonist, terfenadine, alone and in combination on allergen induced immediate bronchoconstriction in man. Thorax. 1987 Dec;42(12):946-52.

58 Rafferty P, Beasley R, Holgate ST. The contribution of histamine to immediate bronchoconstriction provoked by inhaled allergen and adenosine $5^{\prime}$ monophosphate in atopic asthma. Am Rev Respir Dis. 1987 Aug;136(2): 369-73.

59 Taylor IK, O'Shaughnessy KM, Fuller RW, Dollery CT. Effect of cysteinyl-leukotriene receptor antagonist ICI 204.219 on allergen-induced bronchoconstriction and airway hyperreactivity in atopic subjects. Lancet. 1991 Mar 23;337(8743):690-4.

60 Findlay SR, Barden JM, Easley CB, Glass M. Effect of the oral leukotriene antagonist, ICI 204,219 , on antigen-induced bronchoconstriction in subjects with asthma. J Allergy Clin Immunol. 1992 May;89(5):1040-5. 
61 Beasley RC, Featherstone RL, Church MK, Rafferty P, Varley JG, Harris A, et al. Effect of a thromboxane receptor antagonist on PGD2and allergen-induced bronchoconstriction. J Appl Physiol. 1989 Apr;66(4):1685-93.

62 Fahy JV, Fleming HE, Wong HH, Liu JT, Su JQ, Reimann J, et al. The effect of an anti-IgE monoclonal antibody on the early- and latephase responses to allergen inhalation in asthmatic subjects. Am J Respir Crit Care Med. 1997 Jun;155(6):1828-34.

63 Flint KC, Leung KB, Hudspith BN, Brostoff J, Pearce FL, Johnson NM. Bronchoalveolar mast cells in extrinsic asthma: a mechanism for the initiation of antigen specific bronchoconstriction. Br Med J (Clin Res Ed). 1985 Oct 5. 291(6500):923-6.

64 Casale TB, Wood D, Richerson HB, Trapp S, Metzger WJ, Zavala D, et al. Elevated bronchoalveolar lavage fluid histamine levels in allergic asthmatics are associated with methacholine bronchial hyperresponsiveness. J Clin Invest. 1987 Apr;79(4):1197-203.

65 Wardlaw AJ, Dunnette S, Gleich GJ, Collins JV, Kay AB. Eosinophils and mast cells in bronchoalveolar lavage in subjects with mild asthma. Relationship to bronchial hyperreactivity. Am Rev Respir Dis. 1988 Jan;137(1): $62-9$.

66 Broide DH, Gleich GJ, Cuomo AJ, Coburn DA, Federman EC, Schwartz LB, et al. Evidence of ongoing mast cell and eosinophil degranulation in symptomatic asthma airway. J Allergy Clin Immunol. 1991 Oct;88(4):63748.

67 Bradding P, Feather IH, Howarth PH, Mueller R, Roberts JA, Britten K, et al. Interleukin 4 is localized to and released by human mast cells. J Exp Med. 1992 Nov 1;176(5):1381-6.

68 Bradding P, Roberts JA, Britten KM, Montefort S, Djukanovic R, Mueller R, et al. Interleukin- $4,-5$, and -6 and tumor necrosis factor-alpha in normal and asthmatic airways: evidence for the human mast cell as a source of these cytokines. Am J Respir Cell Mol Biol. 1994 May;10(5):471-80.

69 Ying S, Durham SR, Corrigan CJ, Hamid Q, Kay AB. Phenotype of cells expressing mRNA for TH2-type (interleukin 4 and interleukin 5) and TH1-type (interleukin 2 and interferon gamma) cytokines in bronchoalveolar lavage and bronchial biopsies from atopic asthmatic and normal control subjects. Am J Respir Cell Mol Biol. 1995 May;12(5):477-87.

70 Ying S, O’Connor B, Ratoff J, Meng Q, Mallett $\mathrm{K}$, Cousins D, et al. Thymic stromal lymphopoietin expression is increased in asthmatic airways and correlates with expression of Th2-attracting chemokines and disease severity. J Immunol. 2005 Jun 15;174(12):8183-90.

71 Okayama Y, Okumura S, Sagara H, Yuki K, Sasaki T, Watanabe N, et al. FcepsilonRI-mediated thymic stromal lymphopoietin production by interleukin-4-primed human mast cells. Eur Respir J. 2009 Aug;34(2):425-35.
72 Shikotra A, Choy DF, Ohri CM, Doran E, Butler $\mathrm{C}$, Hargadon B, et al. Increased expression of immunoreactive thymic stromal lymphopoietin in patients with severe asthma. J Allergy Clin Immunol. 2012 Jan;129(1):104-9.

73 Sommerhoff CP, Schaschke N. Mast cell tryptase beta as a target in allergic inflammation: an evolving story. Curr Pharm Des. 2007;13(3):313-32.

74 Takai S, Jin D, Miyazaki M. Targets of chymase inhibitors. Expert Opin Ther Targets. 2011 Apr;15(4):519-27.

75 Pejler G. The emerging role of mast cell proteases in asthma. Eur Respir J. 2019 Oct;54(4): 1900685.

76 Pejler G. Novel insight into the in vivo function of mast cell chymase: lessons from knockouts and inhibitors. J Innate Immun. 2020;12(5):357-72.

77 Akdis CA, Blaser K. Histamine in the immune regulation of allergic inflammation. J Allergy Clin Immunol. 2003 Jul;112(1):15-22.

78 Simons FE. Advances in H1-antihistamines. N Engl J Med. 2004 Nov 18;351(21):2203-17.

79 Polosa R. Critical appraisal of antileukotriene use in asthma management. Curr Opin Pulm Med. 2007 Jan;13(1):24-30.

80 Kao CC, Parulekar AD. Spotlight on fevipiprant and its potential in the treatment of asthma: evidence to date. J Asthma Allergy. 2019; $12: 1-5$

81 Harvima IT, Levi-Schaffer F, Draber P, Friedman S, Polakovicova I, Gibbs BF, et al. Molecular targets on mast cells and basophils for novel therapies. J Allergy Clin Immunol. 2014 Sep;134(3):530-44.

82 Lin AM, Rubin CJ, Khandpur R, Wang JY, Riblett M, Yalavarthi S, et al. Mast cells and neutrophils release IL-17 through extracellular trap formation in psoriasis. J Immunol. 2011 Jul 1;187(1):490-500.

83 Hueber AJ, Asquith DL, Miller AM, Reilly J, Kerr S, Leipe J, et al. Mast cells express IL-17A in rheumatoid arthritis synovium. J Immunol. 2010 Apr 1;184(7):3336-40.

84 Appel H, Maier R, Wu P, Scheer R, Hempfing A, Kayser R, et al. Analysis of IL-17(+) cells in facet joints of patients with spondyloarthritis suggests that the innate immune pathway might be of greater relevance than the Th17mediated adaptive immune response. Arthritis Res Ther. 2011 Jun 20;13(3):R95.

85 Noordenbos T, Yeremenko N, Gofita I, van de Sande M, Tak PP, Caňete JD, et al. Interleukin-17-positive mast cells contribute to synovial inflammation in spondylarthritis. Arthritis Rheum. 2012 Jan;64(1):99-109.

86 Patel DD, Lee DM, Kolbinger F, Antoni C. Effect of IL-17A blockade with secukinumab in autoimmune diseases. Ann Rheum Dis. 2013 Apr;72(Suppl 2):ii116-23.
87 Rankin JA, Picarella DE, Geba GP, Temann UA, Prasad B, DiCosmo B, et al. Phenotypic and physiologic characterization of transgenic mice expressing interleukin 4 in the lung: lymphocytic and eosinophilic inflammation without airway hyperreactivity. Proc Natl Acad Sci U S A. 1996 Jul 23;93(15):7821-5.

88 Grunig G, Warnock M, Wakil AE, Venkayya $\mathrm{R}$, Brombacher F, Rennick DM, et al. Requirement for IL-13 independently of IL-4 in experimental asthma. Science. 1998 Dec 18; 282(5397):2261-3.

89 Wills-Karp M, Luyimbazi J, Xu X, Schofield B, Neben TY, Karp CL, et al. Interleukin-13: central mediator of allergic asthma. Science. 1998 Dec 18;282(5397):2258-61.

90 Wilson SJ, Shute JK, Holgate ST, Howarth $\mathrm{PH}$, Bradding P. Localization of interleukin (IL)- 4 but not IL- 5 to human mast cell secretory granules by immunoelectron microscopy. Clin Exp Allergy. 2000 Apr;30(4):493500.

91 Brightling CE, Symon FA, Holgate ST, Wardlaw AJ, Pavord ID, Bradding P. Interleukin-4 and -13 expression is co-localized to mast cells within the airway smooth muscle in asthma. Clin Exp Allergy. 2003 Dec;33(12):17116.

92 Burd PR, Thompson WC, Max EE, Mills FC. Activated mast cells produce interleukin 13 . J Exp Med. 1995 Apr 1;181(4):1373-80.

93 Toru H, Pawankar R, Ra C, Yata J, Nakahata T. Human mast cells produce IL-13 by highaffinity IgE receptor cross-linking: enhanced IL-13 production by IL-4-primed human mast cells. J Allergy Clin Immunol. 1998 Sep; 102(3):491-502.

94 Varadaradjalou S, Féger F, Thieblemont N, Hamouda NB, Pleau JM, Dy M, et al. Toll-like receptor 2 (TLR2) and TLR4 differentially activate human mast cells. Eur J Immunol. 2003 Apr;33(4):899-906.

95 Lee SA, Fitzgerald SM, Huang SK, Li C, Chi DS, Milhorn DM, et al. Molecular regulation of interleukin-13 and monocyte chemoattractant protein-1 expression in human mast cells by interleukin-1beta. Am J Respir Cell Mol Biol. 2004 Sep;31(3):283-91.

96 Tung HY, Plunkett B, Huang SK, Zhou Y. Murine mast cells secrete and respond to interleukin-33. J Interferon Cytokine Res. 2014 Mar;34(3):141-7.

97 Kaur D, Gomez E, Doe C, Berair R, Woodman L, Saunders R, et al. IL-33 drives airway hyper-responsiveness through IL-13-mediated mast cell: airway smooth muscle crosstalk. Allergy. 2015 May;70(5):556-67.

98 Wenzel S, Castro M, Corren J, Maspero J, Wang L, Zhang B, et al. Dupilumab efficacy and safety in adults with uncontrolled persistent asthma despite use of medium-to-highdose inhaled corticosteroids plus a long-acting beta 2 agonist: a randomised double-blind placebo-controlled pivotal phase $2 \mathrm{~b}$ doseranging trial. Lancet. 2016 Jul 2;388(10039): $31-44$. 
99 Deeks ED. Dupilumab: a review in moderate to severe asthma. Drugs. 2019 Nov;79(17): 1885-95.

100 Beck LA, Thaçi D, Hamilton JD, Graham NM, Bieber T, Rocklin R, et al. Dupilumab treatment in adults with moderate-to-severe atopic dermatitis. N Engl J Med. 2014 Jul 10; 371(2):130-9.

101 Simpson EL, Bieber T, Guttman-Yassky E, Beck LA, Blauvelt A, Cork MJ, et al. Two phase 3 trials of dupilumab versus placebo in atopic dermatitis. N Engl J Med. 2016 Dec 15;375(24):2335-48.

102 van der Schaft J, Thijs JL, de Bruin-Weller MS, Balak DMW. Dupilumab after the 2017 approval for the treatment of atopic dermatitis: what's new and what's next? Curr Opin Allergy Clin Immunol. 2019 Aug;19(4):3419.

103 Papi A, Brightling C, Pedersen SE, Reddel HK. Asthma. Lancet. 2018 Feb 24; 391(10122):783-800.

104 Roquet A, Dahlén B, Kumlin M, Ihre E, Anstrén G, Binks S, et al. Combined antagonism of leukotrienes and histamine produces predominant inhibition of allergen-induced early and late phase airway obstruction in asthmatics. Am J Respir Crit Care Med. 1997 Jun;155(6):1856-63.

105 Richter K, Grönke L, Janicki S, Maus J, Jörres RA, Magnussen H. Effect of azelastine, montelukast, and their combination on allergeninduced bronchoconstriction in asthma. Pulm Pharmacol Ther. 2008;21(1):61-6.

106 Davis BE, Illamperuma C, Gauvreau GM, Watson RM, O'Byrne PM, Deschesnes F, et al. Single-dose desloratadine and montelukast and allergen-induced late airway responses. Eur Respir J. 2009 Jun;33(6):13028.

107 Barnes PJ. New therapies for asthma. Trends Mol Med. 2006 Nov;12(11):515-20.

108 Busse W, Corren J, Lanier BQ, McAlary M, Fowler-Taylor A, Cioppa GD, et al. Omalizumab, anti-IgE recombinant humanized monoclonal antibody, for the treatment of severe allergic asthma. J Allergy Clin Immunol. 2001;108(2):184.

109 Milgrom H, Berger W, Nayak A, Gupta N, Pollard S, McAlary M, et al. Treatment of childhood asthma with anti-immunoglobulin E antibody (omalizumab). Pediatrics. 2001;108(2):E36.

110 Holgate ST, Djukanović R, Casale T, Bousquet J. Anti-immunoglobulin E treatment with omalizumab in allergic diseases: an update on anti-inflammatory activity and clinical efficacy. Clin Exp Allergy. 2005 Apr; 35(4):408-16.

111 Sheinkopf LE, Rafi AW, Do LT, Katz RM, Klaustermeyer WB. Efficacy of omalizumab in the treatment of atopic dermatitis: a pilot study. Allergy Asthma Proc. 2008 Sep-Oct; 29(5):530-7.
112 Maurer M, Rosén K, Hsieh HJ, Saini S, Grattan C, Gimenéz-Arnau A, et al. Omalizumab for the treatment of chronic idiopathic or spontaneous urticaria. N Engl J Med. 2013 Mar 7;368(10):924-35.

113 Zhao ZT, Ji CM, Yu WJ, Meng L, Hawro T, Wei JF, et al. Omalizumab for the treatment of chronic spontaneous urticaria: a metaanalysis of randomized clinical trials. J Allergy Clin Immunol. 2016 Jun;137(6):174250.e4.

114 Rafi A, Do LT, Katz R, Sheinkopf LE, Simons CW, Klaustermeyer W. Effects of omalizumab in patients with food allergy. Allergy Asthma Proc. 2010 Jan-Feb;31(1):76-83.

115 Erjefalt JS. Mast cells in human airways: the culprit? Eur Respir Rev. 2014 Sep;23(133): 299-307.

116 Sinniah A, Yazid S, Flower RJ. The anti-allergic cromones: past, present, and future. Front Pharmacol. 2017;8:827.

117 Yang Y, Lu JY, Wu X, Summer S, Whoriskey J, Saris C, et al. G-protein-coupled receptor 35 is a target of the asthma drugs cromolyn disodium and nedocromil sodium. Pharmacology. 2010;86(1):1-5.

118 Guevara JP, Ducharme FM, Keren R, Nihtianova S, Zorc J. Inhaled corticosteroids versus sodium cromoglycate in children and adults with asthma. Cochrane Database Syst Rev. 2006 Apr 19;2006(2):CD003558.

119 van der Wouden JC, Uijen JH, Bernsen RM, Tasche MJ, de Jongste JC, Ducharme F. Inhaled sodium cromoglycate for asthma in children. Cochrane Database Syst Rev. 2008 Oct 8(4):CD002173.

120 Church MK, Hiroi J. Inhibition of IgE-dependent histamine release from human dispersed lung mast cells by anti-allergic drugs and salbutamol. Br J Pharmacol. 1987 Feb; 90(2):421-9.

121 Geahlen RL. Getting Syk: spleen tyrosine kinase as a therapeutic target. Trends Pharmacol Sci. 2014 Aug;35(8):414-22.

122 Lee KS, Lee HK, Hayflick JS, Lee YC, Puri KD. Inhibition of phosphoinositide 3-kinase delta attenuates allergic airway inflammation and hyperresponsiveness in murine asthma model. FASEB J. 2006 Mar;20(3): 455-65.

123 Randis TM, Puri KD, Zhou H, Diacovo TG Role of PI3Kdelta and PI3Kgamma in inflammatory arthritis and tissue localization of neutrophils. Eur J Immunol. 2008 May; 38(5):1215-24.

124 Clemens RA, Lowell CA. CRAC channel regulation of innate immune cells in health and disease. Cell Calcium. 2019 Mar;78:5665.

125 Karra L, Berent-Maoz B, Ben-Zimra M, Levi-Schaffer F. Are we ready to downregulate mast cells? Curr Opin Immunol. 2009 Dec;21(6):708-14.

126 Ekoff M, Nilsson G. Mast cell apoptosis and survival. Adv Exp Med Biol. 2011;716:4760.
127 Linnekin D. Early signaling pathways activated by $\mathrm{c}-\mathrm{Kit}$ in hematopoietic cells. Int J Biochem Cell Biol. 1999 Oct;31(10):105374.

128 Kitamura Y, Go S. Decreased production of mast cells in S1/S1d anemic mice. Blood. 1979 Mar;53(3):492-7.

129 Grimbaldeston MA, Chen CC, Piliponsky AM, Tsai M, Tam SY, Galli SJ. Mast cell-deficient $\mathrm{W}$-sash c-kit mutant Kit W-sh/W-sh mice as a model for investigating mast cell biology in vivo. Am J Pathol. 2005 Sep; 167(3):835-48.

130 Finotto S, Mekori YA, Metcalfe DD. Glucocorticoids decrease tissue mast cell number by reducing the production of the c-kit ligand, stem cell factor, by resident cells: in vitro and in vivo evidence in murine systems. J Clin Invest. 1997 Apr 1;99(7):17218.

131 Djukanovic R, Homeyard S, Gratziou C, Madden J, Walls A, Montefort S, et al. The effect of treatment with oral corticosteroids on asthma symptoms and airway inflammation. Am J Respir Crit Care Med. 1997 Mar: 155(3):826-32.

132 Hattotuwa KL, Gizycki MJ, Ansari TW, Jeffery PK, Barnes NC. The effects of inhaled fluticasone on airway inflammation in chronic obstructive pulmonary disease: a double-blind, placebo-controlled biopsy study. Am J Respir Crit Care Med. 2002 Jun 15;165(12):1592-6.

133 Tsai M, Shih LS, Newlands GF, Takeishi T, Langley KE, Zsebo KM, et al. The rat c-kit ligand, stem cell factor, induces the development of connective tissue-type and mucosal mast cells in vivo. Analysis by anatomical distribution, histochemistry, and protease phenotype. J Exp Med. 1991 Jul 1;174(1): 125-31.

134 Galli SJ, Iemura A, Garlick DS, Gamba-Vitalo C, Zsebo KM, Andrews RG. Reversible expansion of primate mast cell populations in vivo by stem cell factor. J Clin Invest. 1993 Jan;91(1):148-52.

135 Costa JJ, Demetri GD, Harrist TJ, Dvorak AM, Hayes DF, Merica EA, et al. Recombinant human stem cell factor (kit ligand) promotes human mast cell and melanocyte hyperplasia and functional activation in vivo. J Exp Med. 1996 Jun 1;183(6):2681-6.

136 Moller C, Alfredsson J, Engstrom M, Wootz H, Xiang Z, Lennartsson J, et al. Stem cell factor promotes mast cell survival via inactivation of FOXO3a-mediated transcriptional induction and MEK-regulated phosphorylation of the proapoptotic protein Bim. Blood. 2005 Aug 15;106(4):1330-6.

137 Vliagoftis H, Worobec AS, Metcalfe DD The protooncogene c-kit and c-kit ligand in human disease. J Allergy Clin Immunol. 1997 Oct;100(4):435-40. 
138 Kim YK, Nakagawa N, Nakano K, Sulakvelidze I, Dolovich J, Denburg J. Stem cell factor in nasal polyposis and allergic rhinitis: increased expression by structural cells is suppressed by in vivo topical corticosteroids. J Allergy Clin Immunol. 1997 Sep; 100(3):389-99.

139 Kanbe T, Soma Y, Kawa Y, Kashima M, Mizoguchi M. Serum levels of soluble stem cell factor and soluble KIT are elevated in patients with atopic dermatitis and correlate with the disease severity. Br J Dermatol. 2001 Jun;144(6):1148-53.

140 Al-Muhsen SZ, Shablovsky G, Olivenstein R, Mazer B, Hamid Q. The expression of stem cell factor and c-kit receptor in human asthmatic airways. Clin Exp Allergy. 2004 Jun;34(6):911-6.

141 Lei Z, Liu G, Huang Q, Lv M, Zu R, Zhang GM, et al. SCF and IL-31 rather than IL-17 and $\mathrm{BAFF}$ are potential indicators in patients with allergic asthma. Allergy. 2008 Mar;63(3):327-32.

142 Makowska JS, Cieslak M, Kowalski ML. Stem cell factor and its soluble receptor (ckit) in serum of asthmatic patients- correlation with disease severity. BMC Pulm Med. 2009 Jun 1;9:27.

143 Brown JM, Wilson TM, Metcalfe DD. The mast cell and allergic diseases: role in pathogenesis and implications for therapy. Clin Exp Allergy. 2008 Jan;38(1):4-18.

144 Cahill KN, Katz HR, Cui J, Lai J, Kazani S, Crosby-Thompson A, et al. KIT inhibition by imatinib in patients with severe refractory asthma. N Engl J Med. 2017 May 18;376(20): 1911-20.

145 Ustun C, DeRemer DL, Akin C. Tyrosine kinase inhibitors in the treatment of systemic mastocytosis. Leuk Res. 2011 Sep;35(9): 1143-52.

146 Alvarez-Twose I, Matito A, Morgado JM, Sánchez-Muñoz L, Jara-Acevedo M, GarcíaMontero A, et al. Imatinib in systemic mastocytosis: a phase IV clinical trial in patients lacking exon 17 KIT mutations and review of the literature. Oncotarget. 2017 Sep 15; 8(40):68950-63.

147 Edinger AL, Thompson CB. Death by design: apoptosis, necrosis and autophagy. Curr Opin Cell Biol. 2004 Dec;16(6):663-9.

148 Fuchs Y, Steller H. Programmed cell death in animal development and disease. Cell. 2011 Nov 11;147(4):742-58.

149 Zamzami N, Kroemer G. Condensed matter in cell death. Nature. 1999 Sep 9;401(6749): $127-8$.

150 Hengartner MO. The biochemistry of apoptosis. Nature. 2000 Oct 12;407(6805):770-6.

151 Taylor RC, Cullen SP, Martin SJ. Apoptosis: controlled demolition at the cellular level. Nat Rev Mol Cell Biol. 2008 Mar;9(3):23141

152 Cory S, Adams JM. The Bcl2 family: regulators of the cellular life-or-death switch. Nat Rev Cancer. 2002 Sep;2(9):647-56.
153 Elmore S. Apoptosis: a review of programmed cell death. Toxicol Pathol. 2007 Jun;35(4):495-516.

154 Galluzzi L, Vitale I, Aaronson SA, Abrams JM, Adam D, Agostinis P, et al. Molecular mechanisms of cell death: recommendations of the Nomenclature Committee on Cell Death 2018. Cell Death Differ. 2018 Mar;25(3):486-541.

155 Orrenius S, Zhivotovsky B, Nicotera P. Regulation of cell death: the calcium-apoptosis link. Nat Rev Mol Cell Biol. 2003 Jul;4(7): 552-65.

156 Tait SW, Green DR. Mitochondria and cell death: outer membrane permeabilization and beyond. Nat Rev Mol Cell Biol. 2010 Sep;11(9):621-32.

157 Ashkenazi A, Dixit VM. Death receptors: signaling and modulation. Science. 1998 Aug 28;281(5381):1305-8.

158 Cirman T, Oresić K, Mazovec GD, Turk V, Reed JC, Myers RM, et al. Selective disruption of lysosomes in HeLa cells triggers apoptosis mediated by cleavage of bid by multiple papain-like lysosomal cathepsins. J Biol Chem. 2004 Jan 30;279(5):3578-87.

159 Boya P, Kroemer G. Lysosomal membrane permeabilization in cell death. Oncogene. 2008 Oct 27;27(50):6434-51.

160 Droga-Mazovec G, Bojic L, Petelin A, Ivanova S, Romih R, Repnik U, et al. Cysteine cathepsins trigger caspase-dependent cell death through cleavage of Bid and antiapoptotic Bcl-2 homologues. J Biol Chem. 2008 Jul 4;283(27):19140-50.

161 Appelqvist H, Johansson AC, Linderoth E, Johansson U, Antonsson B, Steinfeld R, et al. Lysosome-mediated apoptosis is associated with cathepsin D-specific processing of bid at Phe24, Trp48, and Phe183. Ann Clin Lab SciSum. 2012;42(3):231-42.

162 von Karstedt S, Montinaro A, Walczak H. Exploring the TRAILs less travelled: TRAIL in cancer biology and therapy. Nat Rev Cancer. 2017 May 24;17(6):352-66.

163 Berent-Maoz B, Piliponsky AM, Daigle I, Simon HU, Levi-Schaffer F. Human mast cells undergo TRAIL-induced apoptosis. J Immunol. 2006 Feb 15;176(4):2272-8.

164 Golstein P. Cell death: TRAIL and its receptors. Curr Biol. 1997 Dec 1;7(12):R750-3.

165 Daniels RA, Turley H, Kimberley FC, Liu XS, Mongkolsapaya J, Ch'En P, et al. Expression of TRAIL and TRAIL receptors in normal and malignant tissues. Cell Res. 2005 Jun;15(6):430-8.

166 Karlberg M, Ekoff M, Huang DC, Mustonen P, Harvima IT, Nilsson G. The BH3-mimetic ABT-737 induces mast cell apoptosis in vitro and in vivo: potential for therapeutics. J Immunol. 2010 Aug 15;185(4):2555-62.

167 Peter B, Cerny-Reiterer S, Hadzijusufovic E, Schuch K, Stefanzl G, Eisenwort G, et al. The pan-Bcl-2 blocker obatoclax promotes the expression of Puma, Noxa, and Bim mRNA and induces apoptosis in neoplastic mast cells. J Leukoc Biol. 2014 Jan;95(1):95-104.
168 Reinhart R, Rohner L, Wicki S, Fux M, Kaufmann T. BH3 mimetics efficiently induce apoptosis in mouse basophils and mast cells. Cell Death Differ. 2018 Jan;25(1):20416.

169 Stauffer SR. Small molecule inhibition of the Bcl-X-L-BH3 protein-protein interaction: proof-of-concept of an in vivo chemopotentiator ABT-737. Curr Top Med Chem. 2007; $7(10): 961-5$.

170 Young KW, Piñón LG, Dhiraj D, Twiddy D, MacFarlane M, Hickman J, et al. Mitochondrial fragmentation and neuronal cell death in response to the $\mathrm{Bcl}-2 / \mathrm{Bcl}-\mathrm{x}(\mathrm{L}) / \mathrm{Bcl}-\mathrm{w}$ antagonist ABT-737. Neuropharmacology. 2010 Jun;58(8):1258-67.

171 Plum T, Wang X, Rettel M, Krijgsveld J, Feyerabend TB, Rodewald HR. Human mast cell proteome reveals unique lineage, putative functions, and structural basis for cell ablation. Immunity. 2020 Feb 18;52(2):40416.e5.

172 Blott EJ, Griffiths GM. Secretory lysosomes. Nat Rev Mol Cell Biol. 2002 Feb;3(2):12231.

173 Dragonetti A, Baldassarre M, Castino R, Démoz M, Luini A, Buccione R, et al. The lysosomal protease cathepsin D is efficiently sorted to and secreted from regulated secretory compartments in the rat basophilic/ mast cell line RBL. J Cell Sci. 2000 Sep;113(Pt 18):3289-98.

174 Melo FR, Waern I, Rönnberg E, Åbrink M, Lee DM, Schlenner SM, et al. A role for serglycin proteoglycan in mast cell apoptosis induced by a secretory granule-mediated pathway. J Biol Chem. 2011 Feb 18;286(7): 5423-33.

175 Melo FR, Lundequist A, Calounova G, Wernersson S, Pejler G. Lysosomal membrane permeabilization induces cell death in human mast cells. Scand J Immunol. 2011 Oct 74(4):354-62.

176 Hagforsen E, Paivandy A, Lampinen M Weström S, Calounova G, Melo FR, et al. Ablation of human skin mast cells in situ by lysosomotropic agents. Exp Dermatol. 2015 Jul;24(7):516-21.

177 Abrink M, Grujic M, Pejler G. Serglycin is essential for maturation of mast cell secretory granule. J Biol Chem. 2004 Sep 24; 279(39):40897-905.

178 Melo FR, Grujic M, Spirkoski J, Calounova G, Pejler G. Serglycin proteoglycan promotes apoptotic versus necrotic cell death in mast cells. J Biol Chem. 2012 May 25; 287(22):18142-52.

179 Heading C. Siramesine H Lundbeck. Curr Opin Investig Drugs. $2001 \mathrm{Feb} ; 2$ (2):266-70.

180 Ostenfeld MS, Høyer-Hansen M, Bastholm L, Fehrenbacher N, Olsen OD, Groth-Pedersen $\mathrm{L}$, et al. Anti-cancer agent siramesine is a lysosomotropic detergent that induces $\mathrm{cy}$ toprotective autophagosome accumulation. Autophagy. 2008 May;4(4):487-99. 
181 Spirkoski J, Melo FR, Grujic M, Calounova G, Lundequist A, Wernersson S, et al. Mast cell apoptosis induced by siramesine, a sigma-2 receptor agonist. Biochem Pharmacol. 2012 Dec 15;84(12):1671-80.

182 Hagforsen E, Lampinen M, Paivandy A, Weström S, Velin H, Öberg S, et al. Siramesine causes preferential apoptosis of mast cells in skin biopsies from psoriatic lesions. Br J Dermatol. 2017 Jul;177(1):179-87.

183 Paivandy A, Calounova G, Zarnegar B, Ohrvik H, Melo FR, Pejler G. Mefloquine, an anti-malaria agent, causes reactive oxygen species-dependent cell death in mast cells via a secretory granule-mediated pathway. Pharmacol Res Perspect. 2014 Dec;2(6): e00066.

184 Paivandy A, Sandelin M, Igelström $\mathrm{H}$, Landelius P, Janson C, Melo FR, et al. Induction of human lung mast cell apoptosis by granule permeabilization: a novel approach for targeting mast cells. Front Immunol. 2017;8:1645

185 Paivandy A, Eriksson J, Melo FR, Sellin ME, Pejler G. Lysosomotropic challenge of mast cells causes intra-granular reactive oxygen species production. Cell Death Discov. 2019; 5:95.

186 Kulka M, Alexopoulou L, Flavell RA, Metcalfe DD. Activation of mast cells by doublestranded RNA: evidence for activation through Toll-like receptor 3. J Allergy Clin Immunol. 2004 Jul;114(1):174-82.

187 Matsushima H, Yamada N, Matsue H, Shimada S. TLR3-, TLR7-, and TLR9-mediated production of proinflammatory cytokines and chemokines from murine connective tissue type skin-derived mast cells but not from bone marrow-derived mast cells. J Immunol. 2004 Jul 1;173(1):531-41.

188 Olynych TJ, Jakeman DL, Marshall JS. Fungal zymosan induces leukotriene production by human mast cells through a dectin-1-dependent mechanism. J Allergy Clin Immunol. 2006 Oct;118(4):837-43.

189 Yang Z, Marshall JS. Zymosan treatment of mouse mast cells enhances dectin-1 expression and induces dectin-1-dependent reactive oxygen species (ROS) generation. Immunobiology. 2009;214(4):321-30.

190 Brown MG, McAlpine SM, Huang YY, Haidl ID, Al-Afif A, Marshall JS, et al. RNA sensors enable human mast cell anti-viral chemokine production and IFN-mediated protection in response to antibody-enhanced dengue virus infection. PLoS One. 2012;7(3):e34055.

191 Saluja R, Delin I, Nilsson GP, Adner M. FceR1-mediated mast cell reactivity is amplified through prolonged Toll-like receptor-ligand treatment. PLoS One. 2012;7(8):e43547.

192 Fukuda M, Ushio H, Kawasaki J, Niyonsaba F, Takeuchi M, Baba T, et al. Expression and functional characterization of retinoic acidinducible gene-I-like receptors of mast cells in response to viral infection. J Innate Immun. 2013;5(2):163-73.
193 Lappalainen J, Rintahaka J, Kovanen PT, Matikainen S, Eklund KK. Intracellular RNA recognition pathway activates strong anti-viral response in human mast cells. Clin Exp Immunol. 2013 Apr;172(1):121-8.

194 Malaviya R, Gao Z, Thankavel K, van der Merwe PA, Abraham SN. The mast cell tumor necrosis factor alpha response to FimHexpressing Escherichia coli is mediated by the glycosylphosphatidylinositol-anchored molecule CD48. Proc Natl Acad Sci U S A. 1999 Jul 6;96(14):8110-5.

195 Rocha-de-Souza CM, Berent-Maoz B, Mankuta D, Moses AE, Levi-Schaffer F. Human mast cell activation by Staphylococcus aureus: interleukin-8 and tumor necrosis factor alpha release and the role of Toll-like receptor 2 and CD48 molecules. Infect Immun. 2008 Oct;76(10):4489-97.

196 Enoksson M, Möller-Westerberg C, Wicher G, Fallon PG, Forsberg-Nilsson K, LunderiusAndersson C, et al. Intraperitoneal influx of neutrophils in response to IL-33 is mast celldependent. Blood. 2013 Jan 17;121(3):530-6.

197 Han NR, Oh HA, Nam SY, Moon PD, Kim DW, Kim HM, et al. TSLP induces mast cell development and aggravates allergic reactions through the activation of MDM2 and STAT6. J Invest Dermatol. 2014 Oct; 134(10):2521-30.

198 Hazzan T, Eberle J, Worm M, Babina M. Thymic stromal lymphopoietin interferes with the apoptosis of human skin mast cells by a dual strategy involving STAT5/Mcl-1 and JNK/Bcl-xL. Cells. 2019 Aug 5;8(8):829.

199 Ronnberg E, Ghaib A, Ceriol C, Enoksson M, Arock M, Safholm J, et al. Divergent effects of acute and prolonged interleukin 33 exposure on mast cell IgE-mediated functions. Front Immunol. 2019;10:1361

200 Chen B, Scheding S, Nakeff A, Ruan Q. Differential expression of mast cell growth factor receptor (c-kit) by peritoneal connective tissue-type mast cells and tissue culture-derived mast cells. J Leukoc Biol. 1994 May; 55(5):596-602.

201 Dahl C, Hoffmann HJ, Saito H, Schiøtz PO. Human mast cells express receptors for IL-3, IL-5 and GM-CSF; a partial map of receptors on human mast cells cultured in vitro. Allergy. 2004 Oct;59(10):1087-96.

202 Hauswirth AW, Florian S, Schernthaner GH, Krauth MT, Sonneck K, Sperr WR, et al. Expression of cell surface antigens on mast cells: mast cell phenotyping. Methods Mol Biol. 2006;315:77-90.

203 Wright HV, Bailey D, Kashyap M, Kepley CL, Drutskaya MS, Nedospasov SA, et al. IL3-mediated TNF production is necessary for mast cell development. J Immunol. $2006 \mathrm{Feb}$ 15;176(4):2114-21.

204 Ochi H, Hirani WM, Yuan Q, Friend DS, Austen KF, Boyce JA. T helper cell type 2 cytokine-mediated comitogenic responses and CCR3 expression during differentiation of human mast cells in vitro. J Exp Med. 1999 Jul 19;190(2):267-80.
205 Humbles AA, Lu B, Friend DS, Okinaga S, Lora J, Al-Garawi A, et al. The murine CCR3 receptor regulates both the role of eosinophils and mast cells in allergen-induced airway inflammation and hyperresponsiveness. Proc Natl Acad Sci U S A. 2002 Feb 5; 99(3):1479-84.

206 Brightling CE, Kaur D, Berger P, Morgan AJ, Wardlaw AJ, Bradding P. Differential expression of CCR3 and CXCR3 by human lung and bone marrow-derived mast cells: implications for tissue mast cell migration. J Leukoc Biol. 2005 May;77(5):759-66.

207 Collington SJ, Hallgren J, Pease JE, Jones TG, Rollins BJ, Westwick J, et al. The role of the CCL2/CCR2 axis in mouse mast cell migration in vitro and in vivo. J Immunol. 2010 Jun 1;184(11):6114-23.

208 Venkatesha RT, Berla Thangam E, Zaidi AK, Ali $\mathrm{H}$. Distinct regulation of C3a-induced MCP-1/CCL2 and RANTES/CCL5 production in human mast cells by extracellular signal regulated kinase and PI3 kinase. Mol Immunol. 2005 Mar;42(5):581-7.

209 Nigrovic PA, Malbec O, Lu B, Markiewski MM, Kepley C, Gerard N, et al. C5a receptor enables participation of mast cells in immune complex arthritis independently of Fc $\gamma$ receptor modulation. Arthritis Rheum. 2010 Nov;62(11):3322-33.

210 Schafer B, Piliponsky AM, Oka T, Song CH, Gerard NP, Gerard C, et al. Mast cell anaphylatoxin receptor expression can enhance IgE-dependent skin inflammation in mice. J Allergy Clin Immunol. 2013 Feb;131(2): 541-8.e1-9.

211 Kraft S, Kinet JP. New developments in FcepsilonRI regulation, function and inhibition. Nat Rev Immunol. 2007 May;7(5):36578 .

212 Malbec O, Daëron M. The mast cell IgG receptors and their roles in tissue inflammation. Immunol Rev. 2007 Jun;217:206-21.

213 Motakis E, Guhl S, Ishizu Y, Itoh M, Kawaji $\mathrm{H}$, de Hoon M, et al. Redefinition of the human mast cell transcriptome by deep-CAGE sequencing. Blood. 2014 Apr 24;123(17): e58-67.

214 McNeil BD, Pundir P, Meeker S, Han L, Undem BJ, Kulka M, et al. Identification of a mast-cell-specific receptor crucial for pseudo-allergic drug reactions. Nature. $2015 \mathrm{Mar}$ 12;519(7542):237-41.

215 Matsushima H, Yamada N, Matsue H, Shimada $S$. The effects of endothelin-1 on degranulation, cytokine, and growth factor production by skin-derived mast cells. Eur J Immunol. 2004 Jul;34(7):1910-9.

216 Burton OT, Epp A, Fanny ME, Miller SJ, Stranks AJ, Teague JE, et al. Tissue-Specific expression of the low-affinity IgG receptor, $\mathrm{Fc} \gamma \mathrm{RIIb}$, on human mast cells. Front Immunol. 2018;9:1244. 
217 Royer B, Varadaradjalou S, Saas P, Gabiot AC, Kantelip B, Féger F, et al. Autocrine regulation of cord blood-derived human mast cell activation by IL-10. J Allergy Clin Immunol. $2001 \mathrm{Jul} ; 108(1): 80-6$.

218 Gebhardt T, Lorentz A, Detmer F, Trautwein C, Bektas H, Manns MP, et al. Growth, phenotype, and function of human intestinal mast cells are tightly regulated by transforming growth factor betal. Gut. $2005 \mathrm{Jul}$; 54(7):928-34.

219 Macey MR, Sturgill JL, Morales JK, Falanga YT, Morales J, Norton SK, et al. IL-4 and TGF-beta 1 counterbalance one another while regulating mast cell homeostasis. J Immunol. 2010 May 1;184(9):4688-95.

220 Yokoi H, Myers A, Matsumoto K, Crocker PR, Saito H, Bochner BS. Alteration and acquisition of Siglecs during in vitro maturation of CD34+ progenitors into human mast cells. Allergy. 2006 Jun;61(6):769-76.
221 Yu Y, Blokhuis BRJ, Diks MAP, Keshavarzian A, Garssen J, Redegeld FA. Functional inhibitory siglec- 6 is upregulated in human colorectal cancer-associated mast cells. Front Immunol. 2018;9:2138.

222 Katz HR. Inhibitory receptors and allergy. Curr Opin Immunol. 2002 Dec;14(6):698704.

223 Beghdadi W, Madjene LC, Benhamou M, Charles N, Gautier G, Launay P, et al. Mast cells as cellular sensors in inflammation and immunity. Front Immunol. 2011;2:37.

224 Karra L, Levi-Schaffer F. Down-regulation of mast cell responses through ITIM containing inhibitory receptors. Adv Exp Med Biol. 2011;716:143-59.
225 Gri G, Frossi B, D’Inca F, Danelli L, Betto E, Mion F, et al. Mast cell: an emerging partner in immune interaction. Front Immunol. 2012;3:120.

226 Migalovich-Sheikhet H, Friedman S, Mankuta D, Levi-Schaffer F. Novel identified receptors on mast cells. Front Immunol. 2012; 3:238.

227 Sandig H, Bulfone-Paus S. TLR signaling in mast cells: common and unique features. Front Immunol. 2012;3:185.

228 Lu L, Kulka M, Unsworth LD. Peptide-mediated mast cell activation: ligand similarities for receptor recognition and proteaseinduced regulation. J Leukoc Biol. 2017 Aug; 102(2):237-51.

229 Agier J, Pastwińska J, Brzezińska-Błaszczyk E. An overview of mast cell pattern recognition receptors. Inflamm Res. 2018 Sep;67(9): $737-46$. 